\title{
Synthesis
}

\section{Ecological States and the Resilience of Coral Reefs}

\author{
$\underline{\text { Tim McClanahan }}^{1}, \underline{\text { Nicholas Polunin }}^{2}$, and Terry Done ${ }^{3}$
}

\begin{abstract}
We review the evidence for multiple ecological states and the factors that create ecological resilience in coral reef ecosystems. There are natural differences among benthic communities along gradients of water temperature, light, nutrients, and organic matter associated with upwelling-downwelling and onshoreoffshore systems. Along gradients from oligotrophy to eutrophy, plant-animal symbioses tend to decrease, and the abundance of algae and heterotrophic suspension feeders and the ratio of organic to inorganic carbon production tend to increase. Human influences such as fishing, increased organic matter and nutrients, sediments, warm water, and transportation of xenobiotics and diseases are common causes of a large number of recently reported ecological shifts. It is often the interaction of persistent and multiple synergistic disturbances that causes permanent ecological transitions, rather than the succession of individual short-term disturbances. For example, fishing can remove top-level predators, resulting in the ecological release of prey such as sea urchins and coraleating invertebrates. When sea urchins are not common because of unsuitable habitat, recruitment limitations, and diseases, and when overfishing removes herbivorous fish, frondose brown algae can dominate. Terrigenous sediments carried onto reefs as a result of increased soil erosion largely promote the dominance of turf or articulated green algae. Elevated nutrients and organic matter can increase internal eroders of reef substratum and a mixture of filamentous algae. Local conservation actions that attempt to reduce fishing and terrestrial influences promote the high production of inorganic carbon that is necessary for reef growth. However, global climate change threatens to undermine such actions because of increased bleaching and mortality caused by warm-water anomalies, weakened coral skeletons caused by reduced aragonite availability in reef waters, and increased incidence of diseases in coral reef species. Consequently, many coral reefs, including those that are heavily managed, have experienced net losses in accumulated inorganic carbon in recent decades and appear likely to continue this trend in coming decades. Reefs urgently need to be managed with a view to strengthening their resilience to the increased frequency and intensity of these pressures. Ecological targets must include the restoration or maintenance of species diversity, keystone species, spatial heterogeneity, refugia, and connectivity. Achieving these goals will require unprecedented cooperative synergy between human organizations at all political levels, from intergovernmental to local.
\end{abstract}

* [ERRATUM: A longer version of this paper is published as a book chapter in McClanahan, T.R., N.V.C. Polunin and T.J. Done. 2002. Resilience of coral reefs. in L.H. Gunderson and L. Pritchard Jr. (editors). Resilience and the Behavior of Large-Scale Systems. SCOPE and Island Press, Washington. The original version of this paper stated incorrectly that the book chapter was still in press.]

\section{INTRODUCTION}

Coral reef ecosystems are restricted to tropical latitudes within $30^{\circ}$ of the equator and, compared to other systems, are subject to relatively constant environmental conditions and benign seasonal cycles. Such relative stability may produce organisms and ecosystems that are poorly adapted to environmental fluctuations. For this reason, it can be argued that coral reefs ought to be among the least resilient ecosystems on the planet and may be good indicators of environmental changes such as global climate change
(Glynn 1993, Brown 1997). Coral reefs are nevertheless exposed to significant intra- and interannual variations in environmental conditions, such as changes in temperature and light (Sheppard 2000). Throughout Earth's history, reefs have also been one of the most persistent ecosystems (Veron 1995). However, the species that create reefs have waxed and waned over time, and the species and even taxonomic orders dominant in the present Cenozoic era are significantly different from those of the Mesozoic and Paleozoic eras (Veron 1995). Consequently, there has been considerable debate 
among reef ecologists and geologists over the issue of reef resilience and stability and whether the geologic past is relevant to the scale and types of contemporary disturbances (Brown 1997, Knowlton 2001, Pandolfi 2002).

What is abundantly clear is that, through the combined direct and indirect effects of overfishing, destructive fishing practices, and pollution, the last several hundred years have witnessed direct human pressures on entire functional groups of organisms in oceans and estuaries and on coral reefs (Jackson et al. 2001). Changes in the absolute and relative abundance of functional groups and of their component species may have profound effects on the ability of local communities within the ecosystem to resist and recover from future disturbances. Given the current state of the human influence on coral reefs and the ability of humans to alter the ecology of reefs, it is timely to distinguish the factors that promote the ecological resilience of coral reefs. With this in mind, we examine the literature and review our own case studies, which describe different ecological states and call for management that promotes the property of ecological resilience in coral reefs.

Coral reefs are exposed to a large number of natural and human-influenced disturbances that affect their species and ecological adaptations and organization (Connell 1978, Hughes 1993, Rogers 1993, Brown 1997). Coral reefs appear to be more stable over geologic (Pandolfi 1996, 2002) than ecological time frames (Connell et al. 1997). Over geologic time, which normally encompasses several centuries, the species composition of geologic deposits may remain fairly stable even in the presence of disturbances over ecological time, which ranges from days to decades. In some cases, species composition may change, but total species richness is similar, because newly evolved species can replace those that have become extinct (Jackson et al. 1993, Budd et al. 1996), although the extent of this may vary between ocean basins (Jablonski 1998). Gains and losses of species appear to occur on the scale of millions rather than hundreds of thousands of years, and most extant reef species have been present for the past few million years or a number of glacial cycles (Veron 1995, Jackson et al. 1996)

Despite the potential long-term stability of reefs in the face of many disturbances, there is concern that recent human-induced environmental changes may be exceeding the limits of tolerance of reef organisms to factors such as water temperature, ultraviolet radiation, and predation by humans (Glynn 1993). For example, the warmest temperatures of the last 100,000 yr were only about $1^{\circ} \mathrm{C}$ above today's. To find temperatures $3^{\circ} \mathrm{C}$ warmer, like those predicted for the 21 st century by some global climate change models, one must look back several million years to the Pliocene, when the Earth's and coral reef biota were different (Veron 1995, Livingstone 1996). These changes in background environmental factors are associated with the rapidly rising use of reefs for fisheries and other resource extraction (e.g., coral building blocks, medicine, and others). Recent history suggests that multiple stresses could have variable consequences; few of these stresses counteract each other, and most of them compound each other.

Fig. 1. Diagrammatic representation of the pathways of carbon fixed in coral reef ecosystems (after Done et al. 1996). Total productivity (rate of carbon accumulation in organic and inorganic compartments) is a function of solar radiation, its rate of attenuation through the water column (a function of water clarity) and incoming nutrients and organic matter. The relative sizes of compartments and the fluxes between compartments (thickness of arrows) are mediated by local abundances of organisms. All thus vary with reef location and with depth and zone on an individual reef. Humans, through individual and synergistic pressures of climate change, fishing and pollution can also affect compartments.

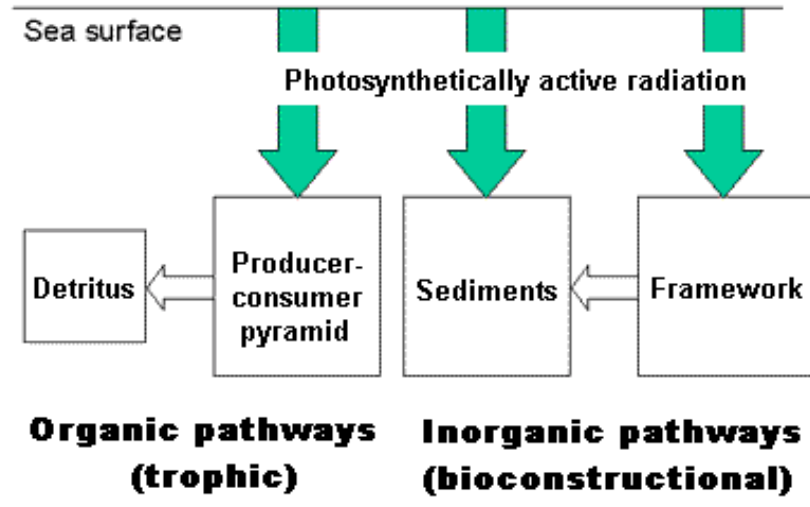

Below, we introduce some widely accepted basic aspects of coral reef ecology and discuss the conditions conducive to both the resilience and nonresilience of ecological structures and functions and their implications for management at different spatial scales. Our analysis relies heavily on a number of recent case studies of environmental and human disturbances. 
Table 1. Energy inputs into a coral reef based on data from East Africa (McClanahan 1990).

\begin{tabular}{lc}
\hline Energy input & Actual energy $\left(\right.$ joules $\left.\cdot \mathrm{m}^{-2} \cdot \mathrm{y}^{-1}\right)$ \\
\hline Solar energy & $7.1 \mathrm{E}+9$ \\
Waves, absorbed & $9.9 \mathrm{E}+8$ \\
Currents, kinetic & $6.6 \mathrm{E}+8$ \\
Tides & $1.1 \mathrm{E}+8$ \\
Rain, physical & $3.1 \mathrm{E}+4$ \\
\hline
\end{tabular}

\section{REEF FUNCTIONS}

One of the simplest ways to view the ecological function of coral reefs is through two of the main outputs of reefs: organic and inorganic (calcium carbonate) carbon production (Fig. 1). Carbon, largely available as bicarbonate ions dissolved in seawater, is fixed by reef organisms for the production, maintenance, and reproduction of the organisms themselves as well as their skeletal structures. The production of skeletal structure or calcium carbonate ranges from 1 to $10 \mathrm{~kg} \cdot \mathrm{m}^{-2} \cdot \mathrm{yr}^{-1}$ (Kinsey 1985,1991 ). Skeletal structure is also broken down into the sediments that form sandy bottoms and beaches and are an important fraction of the inorganic carbon pathway (Fig. 1). In addition, the gross organic production of carbon is high at 1 to $9 \mathrm{gm} \cdot \mathrm{m}^{-2} \cdot \mathrm{d}^{-1}$, which, when wet, is equivalent to 3.5 to $32.2 \mathrm{~kg} \cdot \mathrm{m}^{-2} \cdot \mathrm{yr}^{-}$ ${ }^{1}$ (Crossland et al. 1991). Such production supports the complex and diverse organisms and food webs found on most coral reefs.

Primary production is largely dependent on a variety of algae in four main functional groups: symbiotic algae living in hard corals; fast-growing, filamentous, turf-forming algae (turf algae); larger fleshy or frondose red, brown, and green algae; and algae that deposit calcium carbonate skeletons such as red coralline and green calcareous algae (Steneck and Dethier 1994). Each of these four functional groups exhibits a slightly different balance between organic and inorganic production or tissue growth vs. skeletal or defensive structures.
Zooxanthellae that live in corals are a diverse group of unicellular dinoflagellates (genus Symbiodinium) that supply organic carbon to most corals and derive most of their inorganic nutrients from the coral host. Corals and their zooxanthellae and coralline algae generally have relatively low organic but higher inorganic carbon production, whereas turfs and frondose algae have the opposite pattern (Table 1). As we will show later, reefs can be dominated by different functional groups that can greatly affect the ratios of organic to inorganic production (Table 2).

Undisturbed coral reefs seldom seem severely nutrient limited (Charpy 2001). Field studies indicate that, as water passes over coral reefs, there is no net uptake of phosphorus and an export of nitrogen (Pilson and Betzer 1973, Wilkinson 1984). This indicates that the physicochemical factors that influence the production of both organic and inorganic carbon are primarily dependent on sunlight and water motion from waves, tides, and currents (Table 1). Sunlight is the largest single energy input but the total energy in water motion, i.e., tides, currents and waves combined, is also large and is important for transporting the resources and waste products of the reef (Charpy 2001). Perhaps equally important for maintaining high production is the rate of removal of the primary producers. Rapid removal by dislodgement or grazing maintains an early stage of ecological succession and attendant high photosynthesis and growth rates of turfforming and frondose algae (Carpenter 1988, Choat 1991). Because the removal rate influences net production, some investigators have argued that the abundance of grazers is the main limitation to primary production on coral reefs (Larkum 1983). Secondary consumers such as predators of grazing fish or invertebrates may enhance the production of reefs by maintaining their prey in high growth phases and by supplying concentrated nutrients to their prey (Meyer and Schultz 1985, Polunin 1988, Williams and Carpenter 1988).

\section{Processes, structures, and time scales}

\section{Alternate structures}

Coral reef ecologists have reported a variety of community or ecosystem states that are often described by the dominant organisms or functional groups (Fig. 2). These states are frequently attributed to human influences such as harvesting and pollution. A conceptual model based on the major functional groups (Fig. 2) portrays a variety of ecological states 
that depend on combinations of pollution, fishing, sediments, diseases, natural disturbances such as cyclones, and human management. Because reefs are often exposed to a combination of human and natural influences, individual reefs may be an amalgamation of many of these states.

Fig. 2. A simple conceptual or metamodel describing different common ecological states of coral reefs, with the "most desired state" in the middle box. Also shown are the factors that may cause or maintain these states and possible management interventions (in italics). Individual coral reefs that are exposed to a combination of human and natural influences may be a mosaic of several states.

CORAL REEF RESTORATION METAMODEL

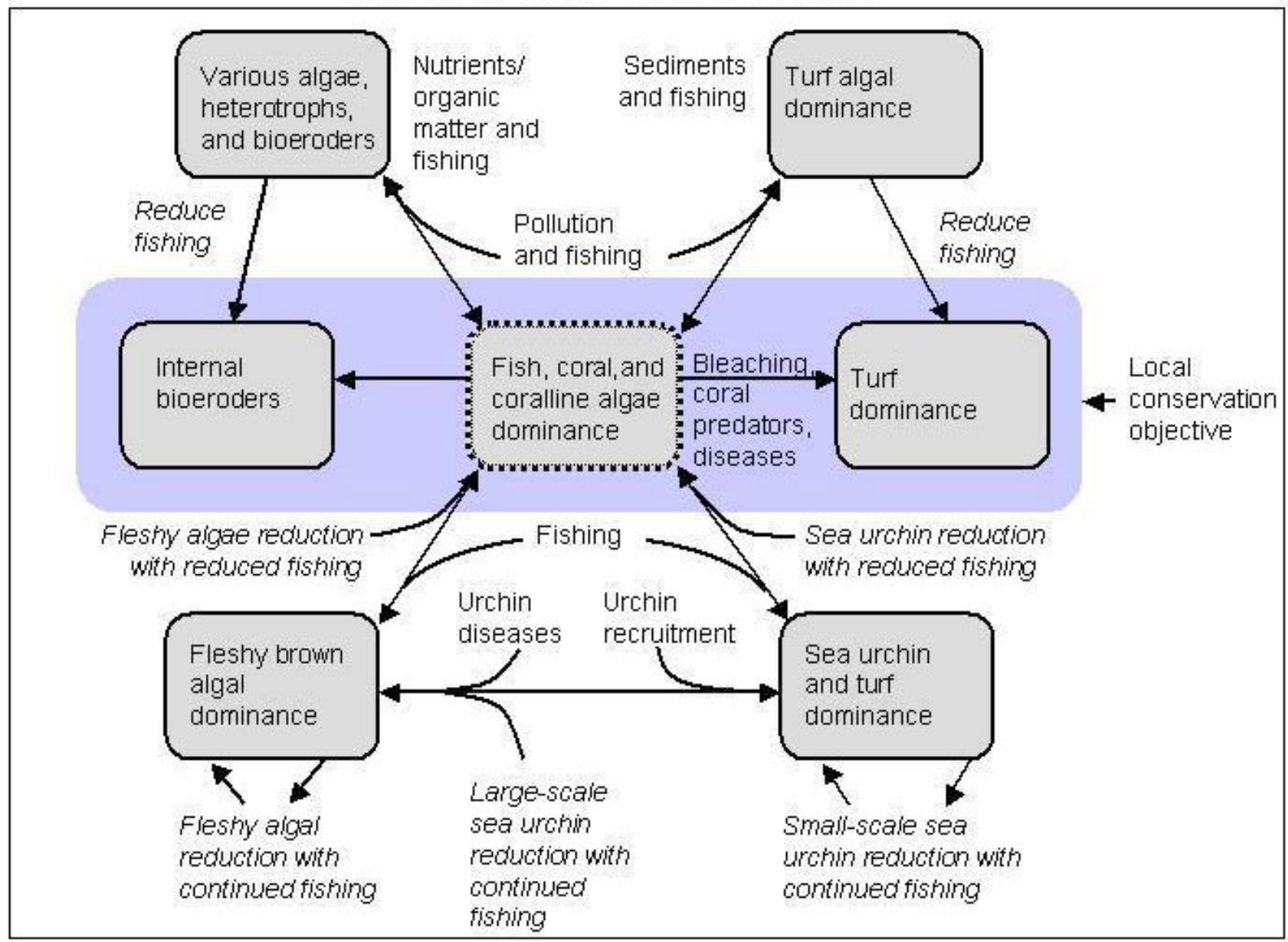

Some researchers believe that increases in the nutrient influx into reef waters may itself cause a switch in dominance from corals to various forms of frondose and filamentous algae and bioeroding sponges (Smith et al. 1981, Rose and Risk 1985, Cuet et al. 1988, Bell 1992, Risk et al. 1995, Lapointe et al. 1997). Nutrification, or the addition of growth-promoting nutrients such as nitrogen and phosphorus, has the potential to increase the growth rates of some fastgrowing algae and heterotrophic invertebrates relative to corals (Littler et al. 1991, LaPointe et al. 1997). However, many studies have shown either a very small or no response to nutrient additions (Kinsey and Domm 1974, Kinsey and Davies 1979, Hatcher and Larkum 1983, Larkum and Steven 1994, Koop et al. 2001). Some algae, such as erect frondose browns, actually decreased under nutrification, whereas others, such as microscopic and filamentous browns, reds, greens, and blue-greens, increased (Browitzka 1972, McClanahan et al. 2002). In the Caribbean, some sites considered to be oligotrophic have high cover of frondose algae (e.g., McClanahan and Muthiga 1998, Ostrander et al. 2000, Williams and Polunin 2001). Whereas an increase in nutrients and algal growth 
might be expected to cause a reef to become dominated by late-successional frondose algae, sponges, and soft corals, the removal of algae often prevents this from occurring. Most importantly, not only herbivory (Hatcher and Larkum 1983, McCook 1999) but also physical disturbances, such as water movement and the saltation of sediments along the sea floor, can frequently reduce the amount of algae and compensate for increased algal growth (McClanahan 1997a). Fishing, which is sometimes associated with a reduction in herbivory and nutrification, may interact with pollution to produce algal growth responses (Fig. 2).

Table 2. Production, production to respiration, and calcification rates on different coral reef substrata based on a summary of the literature (Smith 1983). These are the dominant substrata in the "framework," "pavement," and "sand" zones, respectively, of coral reefs. Varying proportions of one or both of the other substrata may be present in each substratum.

\begin{tabular}{lccc}
\hline Substratum & $\begin{array}{c}\text { Photosynthesis } \\
\left(\mathrm{g} \mathrm{C} \cdot \mathrm{m}^{-2} \cdot \mathrm{d}^{-1}\right)\end{array}$ & Production/respiration & $\begin{array}{c}\text { Calcification } \\
\left(\mathrm{kg} \mathrm{CaCO} \cdot \mathrm{m}^{-2} \cdot \mathrm{y}^{-1}\right)\end{array}$ \\
\hline Continuous coral & 20 & 1 & 10 \\
Algal pavement & 5 & $>1$ & 4 \\
Sand and rubble & 1 & $<1$ & 0.5 \\
\hline
\end{tabular}

The combination of fishing and pollution does not always shift reefs from dominance by corals and earlysuccessional algae to late-successional algae. For example, fishing can promote the abundance of herbivorous sea urchins (Hay 1984, McClanahan and Shafir 1990) that graze intensely and reduce the abundance of algae to levels even lower than those seen when fish dominate grazing (McClanahan 1995a, 1997a). In a second example, when nutrient additions are associated with sediments from a river or a dredging operation, the physical disturbance per se can retard the successional development of algae (McClanahan 1997a, McClanahan and Obura 1997). Additionally, in areas or seasons with high wave or current energy, algae may be constantly disturbed and unable to maintain high levels of abundance (McClanahan et al. 1996). The abundance of macroalgae may also increase in response to an increase in the amount of space available to algae, such as with the loss of coral cover through disease and other disturbances (Williams et al. 2001). Food webs are just one way in which the functional linkages among ecosystem components are manifest, and it is difficult to predict indirect effects in ecosystems from consideration of food webs alone (Polunin and Pinnegar 2002). For example, a number of outcomes are contingent on interactions between pollution and fishing effects (McCook 1999).
Where there is a conservation objective of increasing the abundance and diversity of corals and fishes, managers may recognize one or more of a number of problems, such as overfishing, pollution, or an overabundance or lack of a species resulting in either over- or undergrazing. In many cases, it is important to attempt combinations of management activities, because the outcome will often depend on the interaction of two or more factors (McClanahan et al. 1995, 2001).

\section{Disturbances and reef ecology}

The kinds, scales, duration, and intensities of disturbances vary both regionally and locally (Hughes 1993) and may be modified by human population growth, resource exploitation, and industrialization. Episodic events, i.e., those lasting anywhere from a few hours to several months, that can injure, kill, and collapse most corals over scales of hectares include hurricanes (Woodley et al. 1981, Massel and Done 1993, Rogers 1993, Scoffin 1993, Bythell et al. 2000), fresh water (Hedley 1925), predators (Endean 1976, Moran 1986), stress-related bleaching (Glynn 1993, Brown 1997, Goreau et al. 2000), and sedimentation (Cortes and Risk 1985). Other disturbances, such as the many diseases reported among Caribbean corals in recent years (Richardson 1998), may take years to decades to decimate the local population of corals 
(Antonius 1985, Aronson and Precht 1997). We suggest elsewhere that the quantity, i.e., the frequency, duration, intensity, and distribution, of each of these types of episodic and long-term disturbances has been greatly modified by humans (Intergovernmental Panel for Climate Change 2001). However, most disturbances appear to be qualitatively similar to the types of disturbances that reefs have been experiencing since their origin.

\section{Natural disturbances: cyclones}

There is great geographic variability in the statistical likelihood of a particular coral reef being exposed to strong wave forces. It is negligible in the doldrums, which extend to $10^{\circ}$ north and south of the equator. Reefs between these latitudes are subject instead to weaker monsoonal storms. When and where extreme events do occur, the reefs involved are, at the very least, substantially set back to an earlier successional stage dominated by coral rubble and algal turf. The worst cyclones destroy the entire coral architecture and redistribute rubble and biogenic sediments (Woodley et al. 1981, Dollar and Tribble 1993, Scoffin 1993). Within cyclone latitudes, the expected "cyclone-free" longevity of a massive coral (Massel and Done 1993), which may also be thought of as a surrogate for the longevity of uninterrupted succession, first increases, then decreases with increasing distance from the equator. In some reef areas, the length of each cyclone-free successional run is predicted to shorten as cyclone frequencies increase under current scenarios of global climate change (Done 1999, Pittock 1999).

\section{Population outbreaks of crown-of-thorns starfish}

Populations of the coral-eating crown-of-thorns starfish Acanthaster planci are a normal part of IndoPacific coral reefs. This starfish is the cause of the largest known pest-related disturbances on IndoPacific reef systems, and is regarded as a major management problem (see Moran 1986 and Birkeland and Lucas 1990 for reviews). The starfish eats coral tissue, favoring abundant, fast-growing plate and branching corals but also consuming the tissues of rarer, slow-growing massive types that take much longer to replace themselves (Done 1987, 1988). Since the 1960s, crown-of-thorns starfish have periodically killed $>90 \%$ of the corals on many reefs throughout the region, returning to individual reefs after $\sim 15 \mathrm{yr}$. In the first few years following such outbreaks, algalcovered reef scapes are drab compared to their coral- dominated predecessors and successors.

\section{Human-induced disturbances}

Humanity may be affecting the frequency, duration, intensity, and distribution of many types of disturbance. For any given reef in the Great Barrier Reef, for example, the average interval between cyclone impact and inundation by a flood plume is likely to decrease under all scenarios for global climate change (Pittock 1999). The amount of terrestrial sediments resuspended by these storms and delivered by these floods will likely increase as a result of elevated levels of soil erosion from land used for decades or centuries for various urban, industrial, water conservation, and rural activities. Humans, by fishing down keystone predators (Ormond et al. 1988, McClanahan 1995c) or elevating nutrients (Birkeland 1982), may increase the frequency, intensity, and geographic extent of population outbreaks of coral predators such as crown-of-thorns starfish (Acanthaster planci) and gastropods (Drupella spp.).

\section{Nutrients and sediments}

Early small-scale experiments suggested that the addition of inorganic nutrients had a negative effect on two of the major ecological functions of reefs (Fig. 1): total primary productivity (Kinsey and Domm 1974) and coral calcification (Kinsey and Davies 1979). More recent controlled exposures to ammonium and phosphate, either individually or together, indicated that the most important primary producers, the epilithic algae, may be nutrient sufficient (Larkum and Koop 1997, Koop et al. 2001). In some areas, factors other than nutrients may be limiting to algal production; these include light (Adey and Goertemiller 1987), inorganic carbon supply, space availability (Williams et al. 2001), and, indirectly, water movement (Larkum and Koop 1997). Nutrients may stimulate the production of algae that could potentially overgrow and kill corals (Tanner 1995, Lapointe et al. 1997). Nonetheless, other disturbances such as grazing, waves, and saltation of sediments often compensate for this increased growth (Hatcher and Larkum 1983, McClanahan 1997a, McCook 1999) so that the predicted competitive exclusion does not occur. It appears that many reefs are, therefore, resilient to the addition of inorganic nutrients, and this may be governed by a number of circumstances. Thus, reefs generally have substantial nutrient stores in sediments and biota, and the external supply may be substantial as well (Tribble et al. 1994, Polunin 1996, 
Charpy 2001). There is better evidence, however, that the erosion of reef structure increases with increased nutrients (Risk et al. 1995, Holmes et al. 2000).

Large-scale nutrient additions to reef waters as a result of human activities will generally come from the land, but these additions are often accompanied by other changes in water quality, such as increased concentrations of suspended particulate matter and reduced salinity. Dissolved nutrients quickly stimulate the biomass of phytoplankton. Thus, where large-scale degradation has occurred in inshore reef communities, it cannot be attributed solely to the direct impact of nutrients (Kinsey and Davies 1979, Tomascik and Sanders 1987, Tomascik et al. 1997), because factors such as reduced light or increased sediments are also associated with increases in dissolved nutrients (Yentsch et al. 2002).

Although corals are generally considered to be sensitive to sedimentation effects, the primary framework-building corals vary in their ability to withstand sediment deposition on them, and some may thus be considered resilient (Rogers 1993). Sediment input may change the generic composition of corals without causing a change in the total coral cover (McClanahan and Obura 1997). It may arrest the successional development of algae at the turf stage rather than accelerating it toward frondose algae (McClanahan 1997a). Because the above two studies were undertaken in marine protected areas where fishing was excluded, it was easier to distinguish the effects of river sediment from other human influences. Whatever the specific mechanism, coral reefs in areas with human development can be expected to display ecological changes. These include the maximum depth of water to which corals grow (Tomascik et al. 1997), coral community composition (Randall and Birkeland 1978, van Katwijk et al. 1993), fish abundance and species composition (Amesbury 1981, Green et al. 1997), and processes such as grazing and resuspension of sediment (McCook 1996, Green et al. 1997).

\section{Resource extraction}

Fisheries are the most extensive extractive use of living reefs. Fishing reduces the abundance and mean size of target species such as snappers (Lutjanidae), groupers (Serranidae), grunts (Haemulidae), and emperors (Lethrinidae), and it is evident even on lightly fished reefs that the decline in biomass may be rapid (Jennings and Polunin 1996a). Because many such fishery target species are carnivorous, the abundance of whole trophic groups of fishes, such as invertebrate-feeders, is thought to be sensitive to exploitation.

This swift depletion of target species is the basis for the contention that reefs are sensitive to fishing, and, indeed, the catch per unit of effort does decline in a similar fashion. However, as in other fishery stocks, decline in biomass is evidently accompanied by increased productivity (Jennings and Lock 1996). Fish stocks may therefore be quite resilient to exploitation in productivity terms but less so in terms of species richness and the recovery of species that are slow to colonize and grow (McClanahan 2000).

In spite of earlier impressions to the contrary, reef fishery stocks in the South Pacific are able to support yields that are high per unit of reef area, with fresh weights of $10-30 \mathrm{Mg} \cdot \mathrm{km}^{-2} \cdot \mathrm{yr}^{-1}$. The sustainability of these high levels of productivity is corroborated by modeling studies (Polunin et al. 1996) and by their own persistence in time (> $10 \mathrm{yr}$ ), although, when interpreting existing fisheries yield data, care should be taken with the units of comparison (Munro 1996). Field studies on Kenyan coral reefs suggest that the fish catch through the use of seine nets that capture small fish is reduced on a per-area and per-effort basis compared to sites where this type of gear is not used (McClanahan et al. 1997, McClanahan and Mangi 2001). Modeling studies suggest that catch rates and selection can greatly affect fisheries yields (McClanahan 1995b).

However, substantial contributions to reef fisheries yields may be made from adjacent unexploited coral reefs or from other ecosystems such as seagrass, plankton, and sandy-bottom ecosystems (Polunin 1996). Consequently, high fishing pressure, i.e., more than five persons per square kilometer, may in many such cases be substantially supported by recruitment from distant reefs that are lightly exploited, as may be the case in archipelagoes such as Fiji (Jennings and Polunin 1996a). In Kenyan fringing reef lagoons, where the number of fisher folk exceeds $10 / \mathrm{km}^{2}$, the catch is largely composed of fish that have migrated in from deeper and more lightly fished reefs (McClanahan and Mangi 2001). Additionally, many of the coral-associated species are not an important part of the fisheries at high levels of fishing effort. The catch from coral reefs is frequently composed of species of generalists that are only weakly associated with coral reefs, or of species more frequently associated with other ecosystems or food sources such 
as plankton, sandy bottom, or seagrass meadows.

Fishing has had profound and often indirect influences on reefs in areas such as the Caribbean and East Africa (Fig. 2). A number of studies have shown an increased abundance and diversity of small-bodied damselfish, parrotfish, and wrasses on heavily fished reefs (Russ and Alcala 1989, McClanahan 1994, 1997c) and losses of species at the highest levels of fishing (McClanahan 1994, 1997c, Öhman et al. 1997). A study that compared Kenya's fringing reefs with the patch reefs of Tanzania found a 50\% loss of species diversity on the former but not the latter (McClanahan 1997c). Although this may be due to habitat differences, it seems more likely that the fringing reef environment has the effect of aggregating fisher folk behind the reef, resulting in high fisher population densities (7$\left.14 / \mathrm{km}^{2}\right)$ in shallow $(<5 \mathrm{~m}$ deep) reef and seagrass habitats (McClanahan and Kaunda-Arara 1996, McClanahan et al. 1997). Tanzanian fisher folk are not as numerous $\left(2-4 / \mathrm{km}^{2}\right)$, and reefs are typically separated by deeper water (McClanahan et al. 1999). Consequently, many of the indirect changes associated with fishing may be dependent on the number of fisher folk and their catch selection, which has also been suggested by model simulations (McClanahan 1995b). Fishermen on Fijian reefs are generally less numerous, which may explain the relative lack of ecological change in these fishing grounds.

Where fishing is extensive and "recruitment overfishing" (i.e., overexploitation during the reproductive stages) is common, unsustainable exploitation may occur. In the central Pacific, there is as yet little evidence that these high levels of human disturbance have detrimental side effects on the wider ecosystem. Koslow et al. (1988) presented evidence of changes in the fish community of Jamaican reefs resulting from exploitation. These changes may be most easily explained by the selectivity of the fishing process, and the ecosystem or indirect effects of fishing are not necessarily involved. The expectation that prey fishes, such as those of small size or those of many nontarget groups, should increase in abundance when piscivorous fishes are heavily fished has not been corroborated by work focused on some of the larger target species (Jennings and Lock 1996, Jennings and Polunin 1996a). However, there was evidence of the increased abundance of small-bodied wrasses and damselfish on heavily fished East African reefs (McClanahan 1997c).

\section{Interactions between disturbances}

In many cases, disturbances interact to cause ecological change on coral reefs. For example, one prediction of the effect of sedimentation on coral reefs is that soft corals should increase in abundance (De'ath and Fabricius 2000), although, in Kenya, this happened only in areas with high water movement (McClanahan and Obura 1997). Coral bleaching may also result from a combination of elevated water temperatures, low water movement, and light or ultraviolet radiation (Gleason and Wellington 1993, Brown et al. 1994, Dunne 1994, Nakamura and van Woesik 2001), and each of these factors may modify the level at which bleaching occurs.

\section{Recovery rates of reefs}

In coral reefs, recovery following catastrophic disturbance may or may not result in a return to the predisturbance community structure (Loya 1976, Hatcher 1984, Done 1992, Knowlton 1992, Hughes 1994, McClanahan and Obura 1995). In some cases, individual sites may not fully recover after disturbance, although at the scale of the landscape there is little overall change (Blythell et al. 2000). Whatever the specific details, the rates of recolonization and growth are as much a function of the location of the coral reef as a property of the recolonizing populations (Done et al. 1996). Within large and dense archipelagos arranged along major current systems, such as the Great Barrier Reef, most reefs regularly receive dense aggregations of the larvae released from upstream reefs (Oliver and Willis 1987, Doherty and Williams 1988). In this setting, high degrees of gene flow have been demonstrated in a number of invertebrate (Benzie 1994) and fish taxa (Dudgeon et al. 2000). Nevertheless, there is enormous interannual variation in larval supply and recruitment success among patch reefs and across whole regions (Doherty and Williams 1988).

At reefs separated from their neighbours by great distances and/or located in unfavorable currents, as in French Polynesia (Planes et al. 1993), it seems less likely that larvae from other reefs would arrive on a regular basis (Cowen et al. 2000). There may be intervals of years, decades, or even longer between inputs of exogenous larvae, so that widely separated reefs would be forced to depend more on their own reproductive output (Planes et al. 1993). 
Fig. 3. Graph of the replacement time and territory of the major reef components. Recovery rate is usually less than one month for the microscopic filamentous turfs, a few months for the larger erect fleshy and calcareous algae, years to decades for most reef heterotrophs and decades to millennia for reef structures themselves.

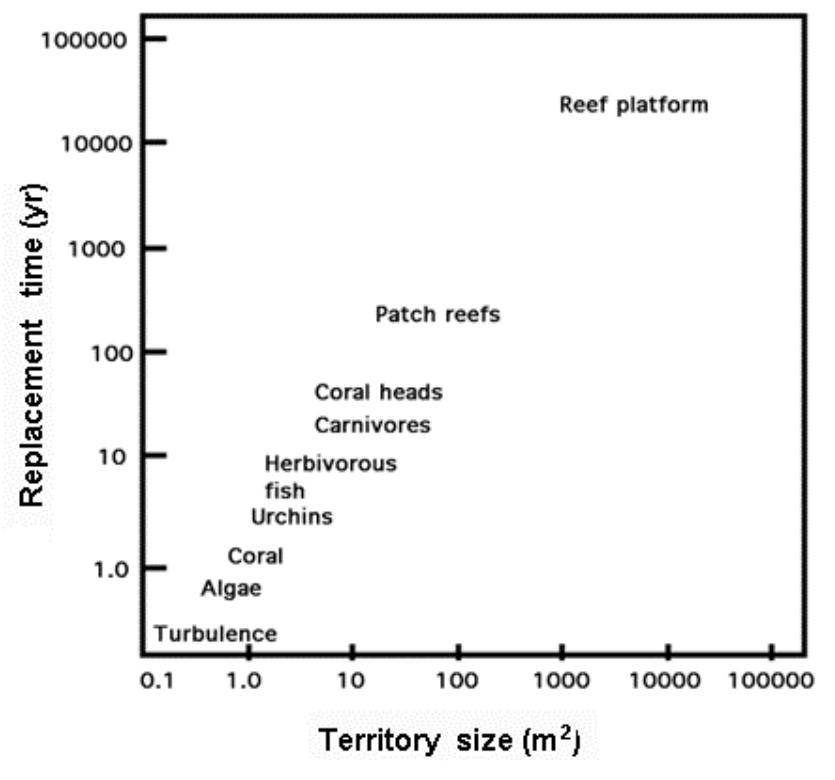

\section{Corals}

The Great Barrier Reef, which is a dense archipelago of individual reefs, would appear to provide optimal conditions for coral settlement, recruitment, and growth following natural disturbance and the return to normal conditions (Done 1992). On slopes severely damaged by crown-of-thorns starfish in the early 1980s, some denuded shallow sites had attained nearly $100 \%$ coral cover after $15 \mathrm{yr}$, whereas deeper sites were mostly $30 \%$ or less. By far the greatest contribution at all depths was made by the same fastgrowing branching and plating corals that were dominant before the predation event. In Indonesia, the same suite of corals colonized a denuded area at a rate exceeding $12 \%$ per year (Tomascik et al. 1996). The rapid linear extension rate of individual corals came, however, at the expense of a marked reduction in skeletal density. Local populations of slow-growing massive corals disturbed by crown-of-thorns sea stars differed greatly in the rate and extent or recovery under different modeled disturbance regimes (Done 1987, 1988). Nowhere was a disturbance interval of less than $15 \mathrm{yr}$ sustainable, with shorter intervals leading to the loss of the larger size classes.

The Great Barrier Reef and Indonesian examples contrast markedly with examples from the Caribbean (Connell 1997). For example, in the Dry Tortugas, coral settlement densities were only a fraction of those observed on the Great Barrier Reef (Kojis and Quinn 1994). Combined with a tiny postsettlement survival rate and poor supply and survival rates of coral fragments, negligible recovery was observed. Studies of Florida coral reefs (Patterson et al. 1997) indicate a continued and widespread negative impact on coral cover by a variety of diseases.

\section{Fishes}

The common larger reef fishes, including coral trout (Ferreira and Russ 1992), parrotfishes (Choat et al. 1996), and snappers may only rarely exceed $25 \mathrm{yr}$ of age. Consequently, if recruitment is sufficient, the time it will take for a depleted stock to approach its unexploited biomass should usually be 12-20 yr. In cases where depletion is less severe, recovery can take place more quickly if the fish population is protected from fishing. This has, in fact, occurred, as indicated by work on marine reserves in the Caribbean (Polunin and Roberts 1993), small-scale fishing in the South Pacific (Smith and Dalzell 1993), and a newly created marine park in Kenya (McClanahan and Kaunda-Arara 1996). Exceptions to such recovery rates can be expected where recruitment is limited, as may be the case at remote sites in the Pacific and certain areas in the Caribbean (Roberts 1995). McClanahan (2000) found that the triggerfish Balistapus undulatus, a keystone predator, was still recovering in marine protected areas after $20 \mathrm{yr}$ of protection from fishing. Additionally, there may be differences in the recovery rates of different fish families or species (McClanahan and Kaunda-Arara 1996), and recovery may also be dependent on the ecological or structural state of the reef. For instance, the recovery rate of reef sites in a newly created marine park appeared to depend on the abundance of sea urchins (McClanahan 1997b). Sites that had been protected from fishing for more than $3 \mathrm{yr}$ showed only minimal recovery over this time, but an experimental sea urchin reduction led to a recovery of corals and fishes (McClanahan 1997b).

\section{Other organisms and reef structure}

Because most reef ecologists have focused on the recovery of corals and fishes, less is known about other groups and the time it takes them to recover from disturbances. However, recovery is often closely related to the territory or size of the individual organisms or the structure of the reef (Fig. 3). 
Most of the primary production is achieved by reef algae, and the recovery rate of these algae is usually less than one month for the microscopic filamentous turfs to a few months for the larger erect frondose and calcareous algae (McClanahan 1997a). The recovery of heterotrophic organisms is usually slower, ranging from years to decades, and the recovery of the reef structures themselves, spanning from massive coral heads to platform reefs, ranges from decades to millennia. Although many of the reef structures we see today were formed during the past $10,000 \mathrm{yr}$ since the last increase in the sea level, in many cases they were built on reef structures of older origin. Reefs deposit calcium carbonate at a rate of about $1 \mathrm{~kg} \cdot \mathrm{m}^{-2} \cdot \mathrm{yr}^{-1}$, which corresponds to a vertical accretion rate of 0.8 $\mathrm{mm} / \mathrm{yr}$, which is near the global sea level rise of 1.3 $\mathrm{mm} / \mathrm{yr}$ over the past $100 \mathrm{yr}$ (Smith 1983). Consequently, reef growth usually keeps pace with glacially induced changes in sea level, but there are some cases, particularly at high latitudes, where reefs can "drown" because they grow too slowly to keep pace with rising sea level (Grigg 1997). Predictions for the increase in the sea level that could result from global warming are as high as $15 \mathrm{~mm} / \mathrm{yr}$, in which case many reefs could potentially drown if this rate persists over a few centuries (Buddemeier and Smith 1988).

\section{Factors that contribute to resilience}

Below we describe some factors, dervied from a number of case studies, that appear to increase the resilience of coral reefs. For our purposes, resilience is defined as the ability of ecosystems to resist lasting change caused by disturbances (Gunderson et al. 1997), and not the return time of an ecosystem after disturbance (Haydon 1994). In many cases, the quality of science is not sufficient to distinguish between alternative explanations, and, in other cases, there may be a number of factors that have either reduced or increased resilience. Consequently, some of the following case studies and explanations should be considered speculative until further studies test the validity of the proposed explanations. The factors that are said to to influence resilience should, therefore, be seen as working hypotheses until properly tested.

\section{Species diversity}

Evidence is accumulating, particularly from terrestrial plant studies (Naeem et al. 1994, Tilman and Downing 1994, Tilman et al. 1996, Chapin et al. 1998), that "functional diversity" is able to stabilize or buffer ecosystem processes such as resource uptake and productivity. Consequently, species diversity may have the capacity to increase ecosystem resilience by ensuring that there is sufficient informational redundancy to guard against the risks associated with environmental disturbances (Naeem 1998). Evidence from coral reefs to support this hypothesis is at present ambiguous. For example, there is little proof that regions with less diversity of corals have lower or more variable rates of calcium carbonate deposition or that areas with less diversity of algae have lower rates of productivity (Kinsey 1983, Smith 1983). Even though some regions have less species diversity than others, all apparently maintain similar functional diversity. Functional diversity appears to be maintained within ecosystems even when there is minimal species diversity. The low number of studies and the limited accuracy of measurements of productivity and net calcium carbonate deposition make any conclusions at this point highly speculative, and future work will need to distinguish between functional and species diversity.

Areas with low species diversity, namely the Eastern Pacific and the Caribbean, have experienced dramatic changes in their ecology during the past few decades. In the Eastern Pacific, the El Niño warming of 1983 led to a series of ecological changes that devastated many of the reefs in the region. High water temperatures caused bleaching and mortality in 70 95\% of the corals in Costa Rica, Panama, Colombia, and Ecuador (Glynn et al. 1988, Glynn and Colgan 1992). High temperatures also extirpated populations of a crustacean guard of Pocillopora, the dominant coral, which left it vulnerable to the sea-star predator Acanthaster planci (Glynn 1987). The final insult to these reefs was a largely unexplained increase in the populations of a sea urchin, Diadema mexicanum, which, through its feeding activities, began to erode the reef framework; as a result, many of the reefs are disappearing (Reaka-Kudla et al. 1996). The type of El Niño that struck in 1983 has a return frequency of once every $100 \mathrm{yr}$, so perhaps the reefs will be able to form and recover on this time scale. However, most Eastern Pacific reefs have low species diversity, seldom form extensive reef flats, and are sparsely distributed.

In the Caribbean, a series of diseases has resulted in a basin-wide reduction in the primary reef-building coral, Acropora palmata (Antonius 1981, Gladfelter 1982, Aronson and Precht 1997, Richardson 1998), and in an important grazer, Diadema antillarum (Lessios et al. 1984). Erect frondose algae now 
dominate many of the reefs in this region (Carpenter 1990a, Hughes 1994, Shulman and Robertson 1997, McClanahan and Muthiga 1998). This, in turn, is suppressing a number of fish species and their grazing rates (McClanahan et al. 2001). Although there are few reported studies, it is fair to assume that these reefs have changed not only with regard to species composition (McClanahan et al. 2001) but also in terms of important ecological processes such as organic production (Carpenter 1988) and inorganic production (Sammarco 1980, 1982). In addition, the recovery rate of corals after disturbances in the lowdiversity Caribbean has been slower than recovery in the high-diversity Indo-Pacific (Connell 1997). Consequently, there is some cause to believe that species diversity increases the capacity of reefs to tolerate and recover from disturbance, but it may also be that these reefs are less diverse because of the history of local disturbances. Clearly, more research into the cause-and-effect mechanisms is required.

\section{Keystone species and redundancy}

It is not clear whether conventional ideas linking diversity and resilience are useful in understanding coral reefs. High species diversity may confer a measure of redundancy that maintains ecological processes when individual species decline (McNaughton 1977, King and Pimm 1983, Tilman et al. 1996, Naeem 1998), even though the stability of individual species can be reduced in high-diversity systems (May 1977, Haydon 1994, but see McCann et al. 1998). In practice, there may be enough biological differences among species that they are not always fully redundant, interchangeable, or replaceable (Rowan et al. 1997). Disturbances may, over the long term, have a more detrimental effect on specialists than on generalists, because the former are often slow growing, site attached, territorial, and competitive dominants ( $K$-selected), whereas the latter frequently exhibit the opposite traits ( $r$-selected). Disturbances to specialists may result in their replacement by fastgrowing and vagile generalists until the specialists recover and reoccupy their niche. Because different species use resources in different ways, the specialists' niche may be only partially filled, so that it cannot always be assumed that generalists will always replace specialists, or that one specialist will play the role of another, even if they appear to be fairly similar to each other ecologically. Consequently, the loss of key species, even in high-diversity systems like coral reefs, can result in changes in reef ecology that alter resource use, productivity, or accretion.

\section{Loss and replacement of keystone species}

\section{Sea-urchin predator case study}

The relationship between sea urchins and their fish predators can greatly affect reef ecology. Because sea urchins have been reported in the stomachs of a large number of fish species (Randall 1967), it might be inferred that one sea urchin predator could easily be replaced by another. However, more careful analyses of sea urchin predators suggest that complete replacement of one predator by another is, in fact, unlikely.

First, many of the species that contain sea urchins in their guts are not actually predators of sea urchins but, rather, scavengers of dead urchins (McClanahan $1995 c, 1999)$. There are fewer true predators than scavenger species, and, in many cases, only one or two species are doing most of the predation (McClanahan $1995 c, 1999,2000)$. Of the eight species of predators of the sea urchin Echinometra mathaei in Kenya, one species, the red-lined triggerfish (Balistapus undulatus) preyed on more than $80 \%$ of the experimental urchins. This fish exhibited sophisticated eating and foraging habits compared to wrasses and scavenger predators (McClanahan 1995c). The other predators were a variety of large, often terminal-male wrasses and a few other invertebrate-feeding fishes (Lethrinidae) that were also common scavengers of sea urchin carcasses. At Mombasa Marine National Park, there was a change in the dominant predator shortly after the cessation of fishing, as the triple-lobed wrasse (Cheilinus trilobatus) was replaced by the red-lined triggerfish during the first few years after the park's creation (McClanahan 2000). Observations indicate that the red-lined triggerfish is aggressive toward other predators such as the triple-lobed wrasse and, as its populations recovered, it was able to reduce the frequency of predation by its competitors.

Although the red-lined triggerfish is uncommon in the shallow lagoons outside of East Africa's marine protected areas, the wrasses and scavenger species are relatively common (McClanahan 1994, 1997c, 2000). The aggressive behavior of the triggerfish, which may make it the competitive dominant in the sea urchin predator guild, is a disadvantage in heavily fished reefs, because it is often among the first species to take bait in traps or on lines. It may also recover slowly after being eliminated by fishing (McClanahan 2000). The red-lined triggerfish is, therefore, uncommon in a well developed fishery, whereas other predators such 
as some of the wrasses and scavengers are able to tolerate fishing disturbances and continue to be common in the catch of mature fisheries (T. R. McClanahan, personal observation). Consequently, many of the fished reefs in East Africa have lost their dominant sea urchin predator through fishing, and the predator role is largely being assumed by other species of wrasse and scavengers.

Sea urchin densities are typically far higher on fished reefs than in older and fully marine protected parks (McClanahan and Shafir 1990, McClanahan 1998). It appears that the subdominant and more naive predators are unable to maintain sea urchin populations at the low levels found in reefs undisturbed by fishing. An increase in its sea urchin population normally has a series of ecological effects on the reef. One beneficial effect of a sea urchin increase is the reduced biomass of frondose algae and possibly increased net production and nitrogen fixation (Carpenter 1988, Williams and Carpenter 1988, McClanahan 1997a). Detrimental effects are the increased erosion of the reef substratum (Birkeland 1988, McClanahan 1995b), competition with and a reduction in the number of herbivorous and other invertebrate-feeding fishes (Carpenter 1990b, Robertson 1991, McClanahan et al. 1994, 1996) and, at the highest levels of sea urchin abundance, a loss of coral cover (Sammarco 1980, McClanahan and Mutere 1994). Consequently, the accumulation of sea urchins is probably associated with an increase in net organic production, but a decrease in inorganic carbon production. Much of this net organic production is not transferred beyond the sea-urchin grazer guild, so it does not benefit fisheries (McClanahan 1995b). In fact, there is accumulating experimental and theoretical evidence that sea urchin dominance reduces fisheries' production (McClanahan 1995b, 1997b, McClanahan et al. 1994, 1996).

In the Caribbean, the queen triggerfish (Balistes vetula) may be the ecological equivalent of the redlined triggerfish in the western Indian Ocean, although experimental evidence is sparse. At remote, but fished, Glovers Reef Atoll, Belize, this species was the third most common predator of Echinometra viridis. The more generalized jolt head porgy (Calamus bajonado Sparidae) was the dominant predator (McClanahan 1999). A similar situation was found during the early stages of the Mombasa Marine National Park, where a subdominant was the main predator because the dominant had not recovered from the effects of fishing. Further research will be needed to test this hypothesis. Queen triggerfish populations have been reduced to such an extent in the Caribbean that the fish is being listed as one of the region's threatened species (Hudson and Mace 1996).

\section{Loss of a sea urchin}

On relatively undisturbed Caribbean reefs, sea urchins and herbivorous fishes both contribute substantially to the maintenance of hard coral cover and recruitment by suppressing algal biomass (Sammarco 1980, 1982, Lewis 1986). It is widely supposed that the blackspined sea urchin (Diadema antillarum) became the principal grazer in shallow Caribbean reef sites (Sammarco 1982) because both its main fish competitors, which include parrotfishes and surgeonfishes, and its predators, which include grunts, triggerfishes, and porgies, were susceptible to fishing pressure (Hughes 1994).

In 1983-1984, when a pathogen decimated $D$. antillarum across the region (Lessios 1988a), other herbivores (Carpenter 1990b, Robertson 1991, McClanahan et al. 1994, 1996) were unable to take its place when it came to controlling algal cover (Hughes et al. 1987, Lessios 1988b, McClanahan 1999). That this phase shift is potentially reversible is indicated by the reduction in macroalgal cover and the increase in the recruitment of 14 coral genera at Discovery Bay since the mid-1990s (Edmunds and Carpenter 2001). On these grounds, it appears the system was once resilient to a coral-algal shift, but its resilience was lost in the face of a pathogen when the grazing function became largely reliant on a single grazer.

However, the relationship between $D$. antillarum and fishing pressure in the Caribbean is undocumented, and mitochondrial DNA evidence indicates that this sea urchin has been abundant there for a few hundred (Jackson 1997) and perhaps a few thousand years (Lessios et al. 2001). Macroalgae were also promoted by coral mortality as a result of cyclones, coral bleaching, diseases (e.g., Williams et al. 2001), and possibly even elevated nutrients (LaPointe et al. 1997, Shulman and Robertson 1997). At depths of 12-15 m on Caribbean reefs, urchins must have been unimportant in reducing macroalgae even before this mass mortality; a negative correlation between the abundance of grazing fish and macroalgal cover indicates that parrotfishes are important in controlling that cover today (Williams and Polunin 2001). Given the probably ongoing susceptibility of $D$. antillarum to the pathogen (e.g., Phinney et al. 2001), a return to balanced grazing by both urchins and grazing fishes is 
desirable in shallow water, but it is not clear how this might be accomplished.

\section{Spatial heterogeneity and refugia}

Coral reefs can be resilient to multiple scales of disturbances (Pandolfi 1996, Connell 1997). One important factor that determines the degree of resilience at a particular place is the scattered patchy distribution of reefs throughout tropical ocean basins (IUCN/UNEP 1988). Individual reefs may be replenished to a greater or lesser extent by recruitment from planktonic larvae derived from other reef sources outside of the disturbed areas (Hughes et al. 1999a). Ocean-wide currents can potentially deliver larvae across hundreds and thousands of kilometers (Roberts 1997), although actual dispersal may be more limited (Cowen et al. 2000). Consequently, the combination of spatial heterogeneity and refugia of reef systems, the temporal heterogeneity of dispersal, and a physically stable but moving transport system of currents ensures the connectivity among reefs that is required for recovery. This is an important aspect of ecological resilience.

\section{Marine parks as refugia}

Heavy fishing is now pervasive throughout the tropics and undoubtedly extends further offshore than in the past. Pollution is often diffuse, and many tropical watersheds are heavily influenced by human activities (Hodgson 1997, LaPointe et al. 1997). Consequently, spatial refuge for many reef organisms and ecosystems is often limited to marine protected areas or deep and remote reefs (McClanahan and Obura 1995). The absence of any systematic differences between effectively protected and unprotected areas in the Caribbean indicates, however, that the linkages between fishing and benthic structure are weak in these reefs (Williams and Polunin 2000). Some theoretical (Bohnsack 1993, Roberts and Polunin 1991,1993), mathematical modeling (DeMartini 1993, Man et al. 1995, Holland and Brazee 1996, Nowlis and Roberts 1999), and field studies (Alcala and Russ 1990, McClanahan and Kaunda-Arara 1996, McClanahan and Mangi 2000) of marine protected areas support the possibility that the total resilience of coral reef fisheries could be increased by providing refuges that contain the habitats required by larger, reproductively mature individuals.

Two field investigations of the fisheries adjacent to marine protected areas in the Sumilon Island Park in the Philippines and the Mombasa Marine National Park (MMNP) suggest that parks can improve fisheries yields to an extent that can partially compensate for the lost fishing area. A 7-yr study of the fish catches adjacent to the MMNP found that, although $65 \%$ of the fishing area was taken up by the park's establishment in 1991, the total catch decreased by only $35 \%$. This was because there was a $110 \%$ increase in the catch per person for the fishers who remained (McClanahan and Mangi 2000).

Once the size of the park was reduced from 10 to 6 $\mathrm{km}^{2}$ in October 1995, the catch quickly increased and then declined to a level just short of the total catch of the area without protection. The coincidence between beach seine exclusion and the reduction in the size of the refuge makes it difficult to distinguish between the effects of the park's size and the fisheries management practices in the areas adjacent to the park's border. However, there was some indication that the degree of spillover depended on the way in which the adjacent areas were managed (McClanahan and Mangi 2000) and on the time since the creation of the protected area (Russ and Alcala 1996, Nowlis and Roberts 1999). In Sumilon Island, however, a similar pattern in fish catch was observed when a small park covering $25 \%$ of the island's reefs stopped functioning and fishing began inside the park. The loss of the park resulted in a 54\% loss in the total yield of fish from the island (Alcala and Russ 1990). The combined results of these experimental management and modeling studies suggest that spillover from such refuges can compensate to some extent for lost fishing grounds and decrease variability in fish catches.

\section{Connectivity}

The replenishment of many populations of reefdwelling organisms relies, more or less, on larvae transported from other reefs by ocean currents (e.g., Hughes et al. 1999a, Cowen 2000). Reef populations that are consistently and reliably replenished are said to be strongly connected to their sources of larvae, whereas those that receive larvae occasionally or unreliably are said to be poorly connected. However, even within the dense archipelago of the Great Barrier Reef, where reefs might all be expected to be strongly interconnected a priori, Hughes et al. (1999a) found profound differences among similar adult coral communities in the strength and reliability of recruitment and in other aspects of population dynamics and turnover. Therefore, being part of an archipelago is no guarantee of strong and reliable 
recruitment of corals at all spatial scales. In contrast, on reefs that are isolated by hundreds or thousands of kilometers from others, the replenishment of the local population depends much more on its own supply of larvae and juveniles. Having a back reef lagoon may be important, because many larvae and juvenile stages may be retained in lagoons during the early stages of development before migrating to deeper reef edges (Swearer et al. 1999, Adams and Ebersole 2002).

Although strong connectivity can help maintain ecological resilience, it can also expose the ecosystem to invasive species, and thereby reduce, or at least challenge, the ecosystem's resilience (Simberloff 1991). This is true when the species assemblage is exposed to novel disturbances such as a new pathogen or a predator of a keystone species as described above for Diadema antillarum. Novelty can challenge the ecosystem's resilience, but it is also arguable that, over the long term, there is self-organization around novel events or organisms. Once this new diversity becomes a nonpathogenic part of the ecosystem, it can become part of the ecosystem's diversity and, therefore, its resilience. This new state may, however, be undesirable to humans (Carpenter et al. 2001). Consequently, the temporal scale of observation of the consequences of a disturbance and the desires of people can result in different conclusions concerning connectivity and resilience.

\section{Synergistic stressors}

The number and extent of environmental stresses can influence the resilience of coral reefs. This occurs because stresses can act in multiplicative rather than additive ways or because the sum of two stresses can exceed a threshold that a single stress would not reach by itself. Consequently, two or more stresses or disturbances working independently may have a much smaller effect than the two factors working together. Inhibitory synergies can also occur when one factor would have an effect except that a second factor is nullifying this influence. There are numerous examples of these types of interactions, and we will briefly describe some examples relevant to coral reef conservation and management.

The largest human influences on coral reefs that are potentially manageable on a local scale are fishing, pollution, and sedimentation (Ginsburg 1994). Because these influences are common throughout the tropics, it has been difficult to distinguish their independent influences. These factors are frequently associated with human population densities, and few governments will establish marine protected areas in polluted waters or allow marine scientists to artificially pollute protected areas. However, there are studies that suggest that the response of coral reefs to a combination of these factors may be different from their response to these factors in isolation (e.g., McCook 1996, 1999, McClanahan and Obura 1997, Umar et al. 1998).

The Malindi-Watamu Marine National Park in Malindi, Kenya, is an example of a protected area that has been nutrified over the last two decades. For the past $50 \mathrm{yr}$, the Park has been receiving increasing sediment and nutrients from the Sabaki River associated with an increase in land uses that promote soil loss (Dunne 1979, Finn 1983). However, this river influence appears to have only a minor effect on the corals (McClanahan and Obura 1997). The total cover of hard coral and the algae benthic cover remained nearly the same over a 7-yr period despite periods of three months or more per year when the waters were brown and turbid. The largest change over the study period was a shift in the species composition of the corals such that those species more tolerant of the increased nutrient and sediment conditions increased and less tolerant species decreased. This minor shift in species composition was unexpected. Many reef ecologists believe that, depending on levels of herbivory and other disturbances to algae, nutrified reefs will be dominated by fast-growing reef algae that will eventually overgrow and kill the corals (Littler et al. 1991, Bell 1992, Delgado and LaPointe 1994, LaPointe et al. 1997).

This unexpected response was probably attributable to two factors: sediments from the river discharge and a lack of fishing. The sediments acted as a physical disturbance that retarded ecological succession to an early-successional turf algae stage rather than a carrier of nutrients that accelerated it toward late-successional algal dominance (McClanahan 1997a). Lack of fishing meant that herbivorous fishes were abundant in this reef, and the persistence of these consumers may have kept late-successional algal abundance in check in spite of the possible stimulation of their growth by nutrients. This interpretation is consistent with the views of many reef ecologists, who suggest that the maintenance of fishes as well as the physical structure of the reef may be important factors inhibiting algal dominance on coral reefs (Szmant 1997, Hughes et al. 1999b, McCook 1999, Miller et al. 2000). These studies suggest that it is often the combined effect of 
the loss of reef consumers, the reef structure, and nutrification that causes large changes in reef ecology. Consequently, if reefs are being nutrified, it may prove useful to restrict or eliminate fishing to improve the chances of maintaining coral and inorganic production.

A second example of increased resilience was shown during a sea-urchin reduction experiment in Mombasa Marine National Park, which was created in 1991 (McClanahan et al. 1994, 1996). Sea urchins are so abundant in many Kenyan reefs that they are considered pests that require active management. Consequently, this study reduced the abundance of sea urchins by about $85 \%$ in the park, as well as at two fished reefs. In the fished reefs (low fish herbivory) where sea urchins were reduced, large frondose algae and seagrasses colonized and reduced living coral by about $35 \%$ over the year of the study. In contrast, the increase in frondose algae in Mombasa Park (high fish herbivory) was smaller and resulted in little change in the coral cover. The reason for these differences was attributed to the greater abundance in the park of surgeonfish and parrotfish, whose numbers increased after the sea urchin reduction and kept frondose algae from increasing and smothering the coral. In unprotected reefs, there was a moderate increase in small-bodied damselfish and juvenile parrotfish, but this increase appeared insufficient to keep frondose algae from dominating the site. As a result, the greater functional diversity of herbivores in the protected areas acted to inhibit the algal overgrowth of the reef and maintain its ecological stability. In general, unfished reefs have greater diversity on the small scale and more ecological redundancy, so they are more likely to buffer the effects of species deletions or reductions. Consequently, to maintain resilience, it behooves managers of coral reefs to maintain species of functional diversity and reduce the number of simultaneous disturbances or stresses.

\section{Human institutions and coral reef resilience}

Humans, through their cultural institutions, have the ability to reduce or increase the resilience of ecosystems depending on various cultural and environmental conditions and interactions. With the exception of the recent rise in tourism and the increased number of marine protected areas, the human relationship with coral reefs has been that of hunter-gatherer, even when the reefs were being exploited by otherwise agrarian or industrialized humans. Below we will describe, from an historical perspective, some case studies of the development and decay of human cultural institutions associated with coral reef fisheries and their relevance to ecological resilience.

\section{The economic development of watersheds}

As human population densities increase in the agricultural communities of watersheds, agricultural labor becomes less limiting, greater partitioning of labor can occur among the various production systems, and a guild of full-time fishers can develop. Fishing becomes less a subsistence activity and more a commercial activity in that fishers will attempt to catch far beyond their household requirements. As human populations increase, fishing can become one of the few ways to meet deficits and earn extra money to support impoverished people. In such cases, fish in near-shore waters may be quickly depleted as fishers adopt boats, technologies, and patterns of movement that allow them to exploit fisheries further offshore.

The development and cultural adoption of fossil fuels and associated technologies have greatly increased fisheries production and reduced the human labor requirement. This has led to further specialization and the accelerated aggregation of populations into towns and cities. Fishing grounds and technologies have consequently expanded. However, in many cases, near-shore fisheries were already fully exploited, with the result that high capital costs and expensive technologies forced many fisheries to go out of business or to expand into offshore waters (Berkes 1987). In such situations, the pressures on fished populations are governed more by the complex interplay of market demands, supply, subsidies, and the cost of fishing, and less by direct interactions between local needs, skills, and effort (Thomson 1980). Costly and/or high-technology fisheries do not necessarily have the highest net profits (Kamukuru 1992).

Associated with the development and expansion of resource use are common patterns of waste production. Sediments and nutrient runoff increase along a gradient from indigenous forest to plantation forest to shifting agriculture to permanent agriculture to pasture (Dunne 1979, Young 1996). Runoff from large tropical cities and towns is seldom treated, and this further adds to the nutrification of the near-shore and coral reef environments. This runoff in combination with fishing adds to the deterioration of the oligotrophic coral reef environment. 


\section{Low islands}

Compared with high islands and continents, the reduced capacity for agriculture on low-lying islands and atolls makes them more dependent on seafood and trade. Consequently, the capacity to maintain human populations on these islands is more limited, and the maintenance of humans may require that they (1) develop trading partners or tourism, (2) rely on offshore fisheries, or (3) develop a fugitive strategy of exploiting resources and moving on. In fact, these three economic strategies and their various combinations are common to many of the low-lying islands of the tropics. For example, the low-lying Maldive Islands off southern India have historically relied almost entirely on the catch of pelagic tuna and until recently did not fish on their reefs (Risk and Sluka 2000). In the past few years, outsiders interested in exporting live fish to other Asian countries have developed reef-based fisheries.

\section{Fisheries management and its contribution to ecological resilience}

To adapt to the changing ratio of human needs to resource abundance, a number of fisheries management policies and actions have been developed (Berkes 1985, Smith 1988, McGoodwin 1990, Smith and Berkes 1991, Berkes et al. 1995). In the early stages of economic development, this often included ways to more fully exploit resources, with little effort toward conservation (Smith 1988). Nonetheless, there is evidence for conservation of resources among smallscale fishers and hunter-gatherer, agrarian, and industrialized cultures that could potentially result in conservation and increased resilience of the human fisheries resource (Johannes 1981, McGoodwin 1990, Smith and Berkes 1991, Zerner 1994, Ruddle 1996, McClanahan et al. 1997). Regardless of the state of the culture, the conservation of resources is achieved mainly through restrictions on (1) gear, (2) access to the resource or the limitation of effort, (3) time limits, (4) size restrictions, and (5) spatial restrictions such as sacred, dangerous, or marine protected areas. Below we will discuss how each of these restrictions has developed in two different cultural situations and their effect on the conservation and ecological resilience of coral reefs.

Small-scale fishing societies: the Mjikenda of East Africa

The Mijikenda are an association of largely agrarian
Bantu people who have lived as a distinct ethnic group along the East African coast for approximately $400 \mathrm{yr}$ (Spear 1978). Their oldest settlement is located in the forest watershed of the East African coastal mountain range, but their second-oldest known settlement is situated just behind a coral-sand beach adjacent to the East African fringing reef (Spear 1978). These people have developed a number of cultural institutions that have parallels with modern fisheries and resource management. These institutions are, however, closely linked to the spiritual view of these people and were not explicitly or, perhaps, consciously developed to manage fisheries or natural resources (McClanahan et al. 1997, Glaesel 1997).

Fish landing sites in this area are now largely managed by a group of elders that includes two "kaya elders" and two leaders of fisheries cooperatives. Kaya elders are traditional leaders who inherit their positions from their fathers and take this leadership role after the death of the father. Fisheries cooperatives are more modern institutions, and their leaders are voted into their positions by the fishers who use the landing site. Kaya elders teach, oversee, and perform traditional cultural ceremonies. Interviews with them indicate that a number of them believe that their ancestors were the ones who originally placed restrictions on the gear used to catch fish, the size of fish caught, access to resources by fishers, and the times when as well as the places where fishing is allowed (McClanahan et al. 1997). For example, if fishers from outside the community would like to fish in the waters adjacent to the landing site, they are expected to pay a fee, called "ubani," to the elders that is regarded as a communal gift to the fishing community. If the fishers are not wanted for any reason, the elders can refuse to accept the ubani, and the foreign fishers are expected to leave and not fish in the waters in which the local community has a proprietary interest. This institution suggests a degree of territorial control of fishing grounds.

Ubani is traditionally used for communal activities, e.g., purchasing goods such as a goat or chicken, rice, and sweets, for the annual sacrifices that these communities perform. During sacrificial times no one is allowed to fish. Additionally, most of these landing sites have a series of areas, called "kaya" or "mzimuare," where these sacrifices are performed. Mzimu are unusual features such as large coral heads, springs, and caves on the beach or at sea that are believed to be inhabited by spirits that can influence fish catches, births, marriages, and other events in 
these peoples' lives. Ancestors identified the mzimu during dreams, and their locations have been passed down through the generations. Traditionally, mzimu were considered dangerous locations because of the spirits, and such sites should be visited only when making sacrifices. Consequently, many of these areas were not fished until recently and might be viewed as traditional marine protected areas, despite the fact that the mzimu area is often very small and this was never their stated purpose.

A recent study examined the utility of these institutional practices in sustaining resources by comparing the traditional knowledge, fish catches, and coral reef ecology adjacent to landing sites maintaining different levels of adherence to these traditions (McClanahan et al. 1997). It was discovered that fish catches adjacent to the two landing sites with the most strict adherence to traditional practices had $40 \%$ higher catches per person than those that did not follow these practices, even though the ecological condition of the reefs was similar and indicated a high level of ecological degradation. One reason for this is that even the more traditional communities did not adhere to all the traditions (e.g., they fished in mzimu, and young fishers used spear guns, which are not condoned by some kaya elders), and they were unable to exclude foreign fishers or those from adjacent landing sites. This was largely because the national institutions, including the police and government fisheries officers, did not allow them to use physical force as part of their enforcement program. These communities were, therefore, limited to passive means of enforcement that included discussions with foreign fishers, not buying or allowing foreign fishers to sell their fish at the landing site, and also pushing their boats onto dry land. Consequently, it was common for foreign fishers to use nontraditional gear such as pullseine nets in the waters of the traditional communities. This created a great deal of animosity between the national government and traditional communities attempting to deal with foreign fishers, and may be one of the reasons for the poor ecological state of their reefs.

\section{Small-scale fishing societies: Fiji and the Pacific}

In the Pacific and Southeast Asia, reef and lagoon resources and areas were widely subject to traditional use rights, and many of these controls persist to this day (Ruddle et al. 1992). In many parts of Indonesia, natural resource use is often subject to traditional laws called "adat," and management systems of the "sasi" type, such as those in parts of the Moluccas, help to constitute a form of coastal territoriality. In Fiji, traditional fishing grounds are known as "qoliqoli." Restraint of the level of exploitation by such practices, which are essentially a form of ownership, is nevertheless strongly contested for many areas of Southeast Asia and Melanesia (Polunin 1984). Carrier (1996) specifically argued, with regard to a site in northern Papua New Guinea with a sophisticated pattern of marine tenure, that resource depletion was unlikely to be recognized. Whatever the origins, there is overwhelming evidence that this customary tenure tended and tends to be opportunistic (Polunin 1984). However, by itself it cannot restrain current resource use when a resource suddenly gains in value or exploitation steadily increases because of human population growth (Tomascik et al. 1996).

The case that the development of customary reef tenure was accompanied by conservation awareness can be made more forcefully for the small islands in the South Pacific where marine resources were an essential source of human sustenance (Johannes 1978). Ruddle et al. (1992) have argued that, in those areas of the South Pacific where customary marine tenure exists, there are plentiful examples of resiliency to outside pressures. However, although the situation in Southeast Asia has not been thoroughly analyzed, the tenure systems in areas such as the Fijian qoliqoli lacked resiliency (Jennings and Polunin 1996b). The Fijian qoliqoli appear to vary substantially in their management aptitude. Specific regulations are variably enforced, with the result that their performance in the face of growing resource pressure is unpredictable (Polunin et al. 1996). The smaller Pacific islands are currently the focus for developing sustainable resource use (Cooke et al. 2000), and, despite the variable performance of existing tenure systems, many will persist and may even be further strengthened by national constitutions. Consequently, any future management regime will have to cooperate with indigenous tenure even if the evidence for its management resiliency to internal or external pressures, and in particular its management aptitude, remains weak. If such resiliency and aptitude could be demonstrated or strengthened, they could be used, in partnership with central government authorities, to maintain resource persistence, or indicate where it is most likely to be achieved through comanagement projects. 


\section{National governments}

National governments can catalyze good environmental and food security outcomes for people who depend heavily on coral reefs through the use of policy and incentive schemes. With their roles of regulator and enforcer as well as financier of public goods and operator of public utilities, governments can interact with both markets and communities. They can influence the other two sectors by supporting research, monitoring resources, and providing education (Done 2001) as well as incentives and enforcement. The East African and Fijian examples above have shown that sustainable use of coral reef resources can be rooted in tradition, but that tradition is flexible (Ruddle 1996). Unsustainable practices may be a consequence of diminishing resource:people ratios in the absence of effective policies set by national governments. The development of effective scientifically based policies should ideally be founded on detailed regional and place-specific descriptions and analyses of the cultural and socioeconomic dimensions of resource use and coral reef ecology, suitably communicated to politicians, policy makers, and resource managers (e.g., Birkeland 1997, Hodgson 1997, Muthiga et al. 2000). National governments in tropical countries seldom have the resources to fully evaluate, monitor, and enforce management practices, but, in cooperation with local and regional leaders, they can influence aspects of resource management and traditions that will increase the chances for resilient or adaptive institutions (Ascher 2001).

\section{CONCLUSION}

Much of the material presented here will be familiar to the coral-reef research fraternity. However we hope to direct the broader community of professional conservation ecologists to some of the issues and dimensions of ecological states and resilience in coral reef ecosystems. The importance of understanding ecological change and the consequences of change on reef states and processes will improve the chance of finding beneficial outcomes in terms of conservation, improved ecological services, ecological resilience, and the sustainable use of resources.

Humans are broadening the use options of coral reefs beyond direct food security for local human populations to include ecological attributes such as biodiversity stewardship, shoreline protection, and tourism. There is thus a great need to monitor coral reef resources and develop a scientific infrastructure and a conceptual platform for the interpretation of the collected data. A key plank of this conceptual platform should be an improved understanding of ecological states, the factors that cause them, and the nature and limits of the resilience of coral reef structures. A comprehensive and holistic understanding is needed to underpin proactive management practices and conservation programs that are supported and implemented by a knowledgeable and adaptable citizenry (Rosenau 1997; Thompson and Trisoglio 1997; Chadwick and Green, in press) that is attuned to principles of precaution (Hass 1997). The cases described above and the factors that promote resilience should be incorporated into practices for managing coral reefs to promote their ecological services into the future.

Responses to this article can be read online at: http://www.consecol.org/vol6/iss2/art18/responses/index.html

\section{LITERATURE CITED}

Adams, A. J., and J. P. Ebersole. 2002. Use of back-reef and lagoon habitats by coral reef fishes. Marine Ecology Progress Series 228:213-226.

Adey, W., and T. Goertemiller. 1987. Coral reef algal turfs: master producers in nutrient poor seas. Phycologia 26:374-386.

Alcala, A. C., and G. R. Russ. 1990. A direct test of the effects of protective management on abundance and yield of tropical marine resources. Journal du Conseil International de la Exploration de la Mer 46:40-47.

Amesbury, S. 1981. Effects of turbidity on shallow water reef fish assemblages in Truk, Eastern Caroline Islands. Pages 491-496 in Volume 6 of the Proceedings of the Fourth International Coral Reef Congress (Manila, 1981). University of the Philippines Marine Science Center, Manila, The Philippines.

Antonius, A. 1981. The 'band' diseases in coral reefs. Pages 6-14 in Volume 2 of the Proceedings of the Fourth Coral Reef Symposium (Manila, 1981). University of the Philippines Marine Science Center, Manila, The Philippines.

Antonius, A. 1985. Coral diseases in the Indo-Pacific: a first record. Bulletin of Marine Ecology 6:197-218.

Aronson, R. B., and W. F. Precht. 1997. Stasis, biological disturbance, and community structure of a Holocene coral reef. Paleobiology 23:336-346.

Ascher, W. 2001. Coping with complexity and 
organizational interests in natural resource management. Ecosystems 4:742-757.

Bell, P. R. F. 1992. Eutrophication and coral reefs: some examples in the Great Barrier Reef lagoon. Water Research 26:553-568.

Benzie, J. A. H. 1994. Patterns of genetic variation in the Great Barrier Reef. Pages 67-79 in A. S. Beaumont, editor. Genetics and evolution of aquatic organisms. Chapman and Hall, London, UK.

Berkes, F. 1985. Fishermen and the "tragedy of the commons." Environmental Conservation 12:199-206.

Berkes, F. 1987. The common property resource problem and the fisheries of Barbados and Jamaica. Environmental Management 11:225-235.

Berkes, F., C. Folke, and M. Gadgil. 1995. Traditional ecological knowledge, biodiversity, resilience and sustainability. Pages 281-299 in C. A. Perrings, K. G. Maler, C. Folke, C. S. Holling, and B. O. Jansson, editors. Biodiversity conservation: problems and policies. Kluwer Academic, Dordrecht, The Netherlands.

Birkeland, C. 1982. Terrestrial runoff as a cause of outbreaks of Acanthaster planci (Echinodermata: Asteroidea). Marine Biology 69:175-185.

Birkeland, C. 1988. The influence of echinoderms on coralreef communities. Echinoderm Studies 3:1-79.

Birkeland, C. 1997. Symbiosis, fisheries and economics development on coral reefs. Trends in Ecology and Evolution 12:364.

Birkeland, C. E., and J. S. Lucas. 1990. Acanthaster planci: major management problem of coral reefs. CRC Press, Boca Raton, Florida, USA.

Bohnsack, J. A. 1993. Marine reserves: they enhance fisheries, reduce conflicts, and protect resources. Oceanus 36:63-71.

Borowitzka, M. A. 1972. Intertidal algal species diversity and the effect of pollution. Australian Journal of Marine and Freshwater Research 23:73-84.

Brown, B. E. 1997. Coral bleaching: causes and consequences. Coral Reefs 16:S129-S138.

Brown, B. E., R. P. Dunne, T. P. Scoffin, and M. D. A. LeTissier. 1994. Solar damage in intertidal corals. Marine Ecology Progress Series 105:219-230.

Budd, A. F., K. G. Johnson, and T. A. Stemann. 1996. Plio-Pleistocene turnover and extinctions in the Caribbean reef-coral fauna. Pages168-204 in J. B. C. Jackson, A. F. Budd, and A. G. Coates, editors. Evolution and environment in tropical America. University of Chicago Press, Chicago, Illinois, USA.
Buddemeier, R. W., and S. V. Smith. 1988. Coral reef growth in an era of rapidly rising sea level: predictions and suggestions for long-term research. Coral Reefs 7 :51-56.

Bythell, J. C., Z. M. Hillis-Starr, and C. S. Rogers. 2000. Local variability but landscape stability in coral reef communities following repeated hurricane impacts. Marine Ecology Progress Series 204:93-100.

Carpenter, R. C. 1988. Mass-mortality of a Caribbean sea urchin: immediate effects on community metabolism and other herbivores. Proceedings of the National Academy of Sciences 85:511-514.

Carpenter, R. C. 1990a. Mass mortality of Diadema antillarum. I. Long-term effects on sea urchin populationdynamics and coral reef algal communities. Marine Biology 104:67-77.

Carpenter, R. C. 1990b. Mass mortality of Diadema antillarum. II. Effects on population densities and grazing intensities of parrotfishes and surgeonfishes. Marine Biology 104:79-86.

Carpenter, S., B. Walker, J. M. Anderies, and N. Abel. 2001. From metaphor to measurement: resilience of what to what? Ecosystems 4:765-781.

Carrier, J. G. 1996. Marine tenure and conservation in Papua New Guinea: problems in interpretation. Pages 142167 in B. J. McCay and J. M. Acheson, editors. The question of the commons: the cuture and ecology of communcal resources. University of Arizona Press, Tucson, Arizona, USA.

Chadwick, V., and A. Green. In press. Managing the Great Barrier Reef Marine Park and World Heritage Area through critical issues management: science and management. In $\mathrm{M}$. K. Kasim Moosa, S. Soemodihardjo, A. Nontji, A. Soegiarto, K. Romimohtarto, Sukarno, and Suharsono, editors. Proceedings of the Ninth International Coral Reef Symposium (Bali, 2000). Indonesian Institute of Sciences and State Ministry for the Environment, Jakarta, Indonesia.

Chapin, F. S., III, E. Sala, I. C. Burke, J. P. Grime, D. U. Hooper, W. K. Lauenroth, A. Lombard, H. A. Mooney, A. R. Mosier, S. Naeem, S. W. Pacala, J. Roy, W. L. Steffen, and D. Tilman. 1998. Ecosystem consequences of changing biodiversity. Bioscience 48:45-52. Available on line

http://www.aibs.org/biosciencelibrary/vol48/jan.98.ecosyste m.html.

Charpy, L. 2001. Phosphorus supply for atoll biological productivity. Coral Reefs 20:357-360.

Choat, J. H. 1991. The biology of herbivorous fishes on coral reefs. Pages 120-155 in P. F. Sale, editor. The ecology of fishes on coral reefs. Academic Press, New York, New York, USA. 
Choat, J. H., L. M. Axe, and D. C. Lou. 1996. Growth and longevity in fishes of the family Scaridae. Marine Ecology Progress Series 145:33-41.

Connell, J. H. 1978. Diversity in tropical rain forests and coral reefs. Science 199:1302-1310.

Connell, J. H. 1997. Disturbance and recovery of coral assemblages. Coral Reefs 16:S101-S113.

Connell, J. H., T. P. Hughes, and C. C. Wallace. 1997. A 30-years study of coral abundance, recruitment, and disturbance at several scales in space and time. Ecological Monographs 67:461-488.

Cooke, A., N. V. C. Polunin, and K. Moce. 2000. Comparative assessment of stakeholder management in traditional Fijian fishing-grounds. Environmental Conservation 27: 291-299.

Cortes, J., and M. J. Risk. 1985. A reef under siltation stress: Cahuita, Costa Rica. Bulletin of Marine Science 36:339-356.

Cowen, R. K., K. M. M. Lwiza, S. Sponaugle, C. B. Paris, and D. B. Olson. 2000. Connectivity of marine populations: open or closed? Science 287:857-859.

Crossland, C. J., B. G. Hatcher, and S. V. Smith. 1991. Role of coral reefs in global ocean production. Coral Reefs 10:55-64.

Cuet, P., O. Naim, G. Faure, and J. Y. Conan. 1988. Nutrient-rich groundwater impact on benthic communities of La Salina fringing reef (Reunion Island, Indian Ocean): preliminary results. Proceedings of the Sixth International Coral Reef Symposium 2:207-212.

Dalzell, P. 1996. Catch rates, selectivity and yields of reef fishing. Pages 161-192 in N. V. C. Poulinin and C. M. Roberts, editors. Reef fisheries. Chapman and Hall, London, UK.

De'ath, G., and K. E. Fabricius. 2000. Classification and regression tree: a powerful yet simple techinique for ecological data analysis. Ecology 81:3178-3192.

Delgado, O., and B. E. Lapointe. 1994. Nutrient-limited productivity of calcareous versus fleshy macroalgae in a eutrophic, carbonate-rich tropical marine environment. Coral Reefs 13:151-159.

DeMartini, E. E. 1993. Modelling the potential of fishery reserves for managing Pacific coral reef fishes. Fishery Bulletin 91:414-427.

Doherty, P. J., and D. M. Williams. 1988. The replenishment of coral reef fish populations. Oceanography and Marine Biology Annual Review 26: 487-551.

Dollar, S. J., and G. W. Tribble. 1993. Recurrent storm disturbance and recovery: a long-term study of coral communities in Hawaii. Coral Reefs 12:223-233.

Done, T. 1992. Constancy and change in some Great Barrier Reef coral communities: 1980-1990. American Zoology 32:665-662.

Done, T. J. 1987. Simulation of the effects of Acanthaster planci on the population structure of massive corals in the genus Porites: evidence of population resilience? Coral Reefs 6:75-90.

Done, T. J. 1988. Simulation of recovery of pre-disturbance size structure in populations of Porites spp. damaged by the crown of thorns starfish Acanthaster planci. Marine Biology 100:51-61.

Done, T. J. 1992. Phase shifts in coral reef communities and their ecological significance. Hydrobiologia 247:121132 .

Done, T. J. 1999. Coral community adaptability to environmental changes at scales of regions, reefs and reef zones. American Zoologist 39: 66-79.

Done, T. J. 2001. Useful science for coral reef management: the Cooperative Research Centre Model. Bulletin of Marine Science 69: 309-315.

Done, T. J., J. C. Ogden, W. J. Wiebe, and B. R. Rosen. 1996. Biodiversity and ecosystem function of coral reefs. Pages 393-429 in H. A. Mooney, J. H. Cushman, E. Medina, O. E. Sala, and E.-D. Schulze, editors. Functional roles of biodiversity: a global perspective. John Wiley, New York, New York, USA.

Dudgeon, C. L., N. Gust, and D. Blair. 2000. No apparent genetic basis to demographic differences in scarid fishes across continental shelf of the Great Barrier Reef. Marine Biology 137:1059-1066.

Dunne, R. P. 1994. Radiation and coral bleaching. Nature 368:697.

Dunne, T. 1979. Sediment yield and land use in tropical catchments. Journal of Hydrology 42:281-300.

Edmunds, P. J., and R. C. Carpenter. 2001. Recovery of Diadema antllarum reduces macroalgal cover and increases abundance of juvenile corals on a Caribbean reef. Proceedings of the National Academy of Science 98:50675071.

Endean, R. 1976. Destruction and recovery of coral communities. Pages 215-254 in A. O. Jones and R. Endean, editors. Biology and geology of coral reefs: biology two. Academic Press, New York, New York, USA.

Ferreira, B. P., and G. R. Russ. 1992. Age, growth and mortality of the inshore coral trout Plectropomus maculatus (Pisces: Serranidae) from the Central Great Barrier Reef, Australia. Australian Journal of Marine and Freshwater Research 43:1301-1312. 
Finn, D. 1983. Land use and abuse in the East African region. Ambio 12:296-301.

Ginsburg, N. R. 1994. Proceedings of the Colloquium on Global Aspects of Coral Reefs Health, Hazards and History. University of Miami, Rosensteil School of Marine and Atmospheric Science, Miami, Florida, USA.

Gladfelter, W. B. 1982. White-band disease in Acropora palmata: implications for the structure and growth of shallow reefs. Bulletin of Marine Science 32:639-645.

Glaesel, H. 1997. Fishers, parks, and power: the socioenvironmental dimensions of marine resource decline and protection on the Kenya Coast. Dissertation. University of Wisconsin-Madison, Madison, Wisconsin, USA.

Gleason, D. F., and G. M. Wellington. 1993. Ultraviolet radiation and coral bleaching. Nature 365:836-838.

Glynn, P. W. 1987. Some ecological consequences of coral-crustacean guard mutualisms in the Indian and Pacific Oceans. Symbiosis 4:301-324.

Glynn, P. W. 1993. Coral reef bleaching: ecological perspectives. Coral Reefs 12:1-17.

Glynn, P. W., and M. W. Colgan. 1992. Sporadic disturbances in fluctuating coral reef environments: El Niño and coral reef development in the eastern Pacific. American Zoology 32:707-718.

Glynn, P. W., J. Cortez, H. M. Guzman, and R. H. Richmond. 1988. EI Niño (1982-83) associated coral mortality and relationships to sea surface temperature deviations in the tropical eastern Pacific. Pages 237-243 in Volume 1 of the Proceedings of the Sixth International Coral Reef Symposium (Townsville, 1988). Australian Institute of Marine Science, Townsville, Australia.

Goreau, T., T. McClanahan, R. Hayes, and A. Strong. 2000. Conservation of coral reefs after the 1998 global bleaching event. Conservation Biology 14:5-15.

Green, A. L., C. Birkeland, R. H. Randall, B. D. Smith, and S. Wilkins. 1997. 78 years of coral reef degradation in Pago Harbor: a quantitative record. Pages 1883-1888 in Volume 2 of the Proceedings of the Eighth International Coral Reef Symposium (Panama City, 1997). Smithsonian Tropical Research Institute, Panama City, Panama.

Grigg, R. W. 1997. Paleoceanography of coral reefs in the Hawaiian-Emperor Chain revisited. Coral Reefs 16:S33S38.

Gunderson, L. H., C. S. Holling, L. Pritchard, and G. D. Peterson. 1997. Resilience in ecosystems, institutions, and societies. Beijer Discussion Paper Series, Number 95. Beijer International Institute of Ecological Economics, Royal Swedish Academy of Sciences, Stockholm, Sweden.

Haas, P. M. 1997. Scientific communities and multiple paths to environmental management. Pages 193-228 in L. A. Brooks and S. D. Vandeveer, editors. Saving the seas: values, scientists, and international governance. Cornell Maritime Press, Centreville, Maryland, USA.

Hatcher, B. G. 1984. A maritime accident provides evidence for alternate stable states in benthic communities on coral reefs. Coral Reefs 3:199-204.

Hatcher, B. G., and A. W. D. Larkum. 1983. An experimental analysis of factors controlling the standing crop of the epilithic algal community on a coral reef. Journal of Experimental Marine Biology and Ecology 69:61-84.

Hay, M. E. 1984. Patterns of fish and urchin grazing on Caribbean coral reefs: are previous results typical? Ecology 65:446-454.

Haydon, D. 1994. Pivotal assumptions determining the relationship between stability and complexity: an analytical synthesis of the stability-complexity debate. American Naturalist 144:14-29.

Hedley, C. 1925. The natural destruction of a coral reef: report of the Great Barrier Reef Committee. Transactions of the Royal Geographical Society of Australasia (Queensland) 1:35 - 40.

Hodgson, G. 1997. Resource use: conflicts and management solutions. Pages 386-410 in C. Birkeland, editor. Life and death of coral reefs. Chapman and Hall, New York, New York, USA.

Holland, D. S., and R. J. Brazee. 1996. Marine reserves for fisheries management. Marine Resource Economics 11:157-171.

Holmes, K. E., E. N. Edinger, INITIALS?? Hariyadi, G. V. Limmon, and M. J. Risk. 2000. Bioerosion of live massive corals and branching coral rubble on Indonesian coral reefs. Marine Pollution Bulletin 40:606-617.

Hudson, E., and G. Mace. 1996. Marine fish and the IUCN red list of threatened animals. International Union for Conservation of Nature and Natural Resources, Gland, Switzerland.

Hughes, T. P. 1993. Disturbance: effects on coral reef dynamics. Coral Reefs 12:115.

Hughes, T. P. 1994. Catastrophes, phase shifts, and largescale degradation of a Caribbean coral reef. Science 265:1547-1551.

Hughes, T. P., A. H. Baird, E. A. Dinsdale, N. A. Moltschaniwskyj, M. S. Pratchett, J. E. Tanner, and B. L. Willis. 1999a. Patterns of recruitment and abundance of corals along the Great Barrier Reef. Nature 397:59-63.

Hughes, T. P., D. C. Reed, and M. J. Boyle. 1987. Herbivory on coral reefs: community structure following 
mass mortalities of sea urchins. Journal of Experimental Marine Biology and Ecology 113:39-59.

Hughes, T., A. M. Szmant, R. Steneck, R. Carpenter, and S. Miller. 1999b. Algal blooms on coral reefs: what are the causes? Limnology and Oceanography 44:1583-1586.

Intergovernmental Panel for Climate Change. 2001. Summary for policymakers: a report of Working Group I of the Intergovernmental Panel on Climate Change. World Meteorological Organization, Geneva, Switzerland. Available online at: http://www.ipcc.ch/pub/spm22-01.pdf.

IUCN/UNEP. 1988. Coral reefs of the world. International Union for Conservation of Nature and Natural Resources/UNEP, Gland, Switzerland.

Jablonski, D. 1998. Geographic variation in the molluscan recovery from the end-cretaceous extinction. Science 279:1327-1330.

Jackson, J. B. C. 1997. Reefs since Columbus. Coral Reefs 16:S23-S32.

Jackson, J. B. C., A. F. Budd, and A. G. Coates. 1996. Plio-pleistocene turnover and extinctions in the Caribbean reef-coral fauna. Pages169-204 in J. B. C. Jackson, A. F. Budd, and A. G. Coates, editors. Evolution and environment in tropical America. University of Chicago Press, Chicago, Illinois, USA.

Jackson, J. B. C., P. Jung, A. G. Coates, and L. S. Collins. 1993. Diversity and extinction of tropical American mollusks and emergence of the Isthmus of Panama. Science 260:1624-1629.

Jackson, J. B. C., M. X. Kirby, W. H. Berger, K. A. Bjorndahl, L. W. Botsford, B. J. Bourque, R. H. Bradbury, R. Cooke, J. Erlandson, J. A. Estes, T. P. Hughes, S. Kidwell, C. B. Lange, H. S. Lenihan, J. M. Pandolfi, C. H. Peterson, R. S. Steneck, M. J. Tegner, and R. R. Warner. 2001. Historical overfishing and the recent collapse of coastal ecosystems. Science 293:629-638.

Jennings, S., and J. M. Lock. 1996. Population and ecosystem effects of fishing. Pages 193-218 in N. V. C. Polunin and C. M. Roberts, editors. Tropical reef fisheries. Chapman and Hall, London, UK.

Jennings, S., and N. V. C. Polunin. 1995a. Comparative size and composition of yield from six Fijian reef fisheries. Journal of Fisheries Biology 46:28-46.

Jennings, S., and N. V. C. Polunin. 1995b. Relationships between catch and effort in Fijian multispecies reef fisheries subject to different levels of exploitation. Fisheries Management and Ecology 2:89-101.

Jennings, S., and N. V. C. Polunin. 1996a. Effects of fishing effort and catch rate upon the structure and biomass of Fijian reef fish communities. Journal of Applied Ecology 33:400-412.
Jennings, S., and N. V. C. Polunin. 1996b. Impacts of fishing on tropical reef ecosystems. Ambio 25:44-49.

Johannes, R. E. 1978. Traditional marine conservation methods in Oceania and their demise. Annual Review of Ecology and Systematics 9:349-364.

Johannes, R. E. 1981. Words of the lagoon: fishing and marine lore in the Palau district of Micronesia. University of California Press, Berkeley, California, USA.

Kamukuru, A. T. 1992. Costs and earnings of basket trap and handline fishery in the Dar-es-Salaam region of Tanzania. Thesis. University of Kuopio, Kuopio, Finland.

King, A. W., and S. I. Pimm. 1983. Complexity, diversity, and stability: a reconciliation of theoretical and empirical results. American Naturalist 122:229-239.

Kinsey, D. W. 1983. Standards of performance in coral reef primary production and carbon turnover. Pages 209-220 in D. J. Barnes, editor. Perspectives on coral reefs. Brian Clouston Publisher, Manuka, Australia.

Kinsey, D. W. 1985. Metabolism, calcification and carbon production. I. System level studies. Pages 505-526 in Volume 4 of the Proceedings of the Fifth International Coral Reef Congress (Tahiti, 1985). Antenne MuseumEPHE, Moorea, French Polynesia.

Kinsey, D. W. 1991. The coral reefs: an owner-built, highdensity, fully-serviced, self-sufficient housing estate in the desert—or is it? Symbiosis 10:1-22.

Kinsey, D. W., and P. J. Davies. 1979. Effects of elevated nitrogen and phosphorus on coral reef growth. Limnology and Oceanography 24:935-940.

Kinsey, D. W., and A. Domm. 1974. Effects of fertilisation on a coral reef environment: primary production studies. Pages 49-66 in Volume of the Proceedings of the Second International Symposium on Coral Reefs (Brisbane, 1973). Great Barrier Reef Committee, Brisbane, Australia.

Knowlton, N. 1992. Thresholds and multiple stable states in coral reef community dynamics. American Zoologist 32:674-682.

Knowlton, N. 2001. The future of coral reefs. Proceedings of the National Academy of Science 98:5419-5425.

Kojis, B. L., and N. J. Quinn. 1994. Biological limits to Caribbean reef recovery: a comparison with western and south Pacific reefs. Pages 353-359 in Proceedings of the Colloquium on Global Aspects of Coral Reefs: Health, Hazards and History (Miami, 1993). University of Miami, Rosensteil School of Marine and Atmospheric Sciences, Miami, Florida.

Koop, K., D. Booth, A. Broadbent, J. Brodie, D. Bucher, D. Capone, J. Coll, W. Dennison, M. Erdmann, P. Harrison, O. Hoegh-Guldberg, P. Hutchings, G. B. 
Jones, A. W. D. Larkum, J. O. O'Neil, A. Steven, E. Tentor, S. Ward, J. Williamson, and D. Yellowlees. 2001. ENCORE: the effect of nutrient enrichment on coral reefs; synthesis of results and conclusions. Marine Pollution Bulletin 42:91-120.

Koslow, J. A., F. Hanley, and R. Wicklund. 1988. Effects of fishing on reef fish communities at Pedro Bank and Port Royal Cays, Jamaica. Marine Ecology Progress Series 43:201-212.

Lapointe, B. E., M. M. Littler, and D. S. Littler. 1997. Macroalgal overgrowth of fringing coral reefs at discovery Bay, Jamaica: bottom-up versus top-down control. Pages 927-932 in Volume 1 of the Proceedings of the Eighth International Coral Reef Symposium (Panama City, 1997). Smithsonian Tropical Research Institute, Panama City, Panama.

Larkum, A. W. D., and K. Koop. 1997. Encore, algal productivity and possible paradigm shifts. Pages 881-884 in Volume 1 of the Proceedings of the Eighth International Coral Reef Symposium (Panama City, 1997). Smithsonian Tropical Research Institute, Panama City, Panama.

Larkum, A. W. D., and A. D. L. Steven. 1994. Encore: the effect of nutrient enrichment on coral reef. 1. Experimental design and research programme. Marine Pollution Bulletin 29:112-120.

Larkum, W. D. 1983. The primary productivity of plant communities on coral reefs. Pages 221-230 in D. J. Barnes, editor. Perspectives on coral reefs. Brian Clouston Publisher, Manuka, Australia.

Lessios, H. A. 1988a. Mass mortality of Diadema antillarum in the Caribbean: what have we learned? Annual Review of Ecology and Systematics 19:371-393.

Lessios, H. A. 1988b. Population dynamics of Diadema antillarum (Echinodermata: Echinoidea) following mass mortality in Panama. Marine Biology 99:515-526.

Lessios, H. A., M. J. Garrido, and B. D. Kesing. 2001. Demographic history of Diadema antillarum, a keystone herbivore on Caribbean reefs. Proceedings of the Royal Society of London B 268: 1-7.

Lessios, H. A., D. R. Robertson, and J. D. Cubit. 1984. Spread of Diadema mass mortality through the Caribbean. Science 226:335-337.

Lewis, S. A. 1986. The role of herbivorous fishes in the organization of a Caribbean reef community. Ecological Monographs 56:183-200.

Littler, M. M., D. S. Littler, and E. A. Titlyanov. 1991. Comparisons of $\mathrm{N}$ - and P-limited productivity between high granitic islands versus low carbonate atolls in the Seychelles Archipelago: a test of the relative-dominance paradigm. Coral Reefs 10:199-209.
Livingstone, D. A. 1996. Historical ecology. Pages 3-17 in T. R. McClanahan and T. P. Young, editors. East African ecosystems and their conservation. Oxford University Press, New York, New York, USA.

Loya, Y. 1976. Recolonisation of Red Sea corals affected by natural catastrophes and man-made perturbations. Ecology 57:278-289.

Man, A., R. Law, and N. V. C. Polunin. 1995. Role of marine reserves in recruitment to reef fisheries: a metapopulation model. Biological Conservation 71:197204.

Massel, S. R., and T. J. Done. 1993. Effects of cyclone waves on massive coral assemblages on the Great Barrier Reef: meteorology, hydrodynamics and demography. Coral Reefs 12:153-166.

May, R. M. 1977. Thresholds and breakpoints in ecosystems with a multiplicity of stable states. Nature 269:471-477.

McCann, K., A. Hastings, and G. R. Huxel. 1998. Weak trophic interactions and the balance of nature. Nature 395: 794-798.

McClanahan, T. R. 1990. Hierarchical control of coral reef ecosystems. Dissertation. University of Florida, Gainesville, Florida, USA.

McClanahan, T. R. 1994. Kenyan coral reef lagoon fish: effects of fishing, substrate complexity, and sea urchins. Coral Reefs 13:231-241.

McClanahan, T. R. 1995a. Harvesting in an uncertain world: impact of resource competition on harvesting dynamics. Ecological Modelling 80:21-26.

McClanahan, T. R. 1995b. A coral reef ecosystemfisheries model: impacts of fishing intensity and catch selection on reef structure and processes. Ecological Modelling 80:1-19.

McClanahan, T. R. 1995c. Fish predators and scavengers of the sea urchin Echinometra mathaei in Kenyan coral-reef marine parks. Environmental Biology of Fishes 43:187-193.

McClanahan, T. R. 1997a. Primary succession of coralreef algae: differing patterns on fished versus unfished reefs. Journal of Experimental Marine Biology and Ecology 218:77-102.

McClanahan, T. R. 1997b. Recovery of fish populations from heavy fishing: does time heal all? Pages 2033-2038 in Volume 2 of the Proceedings of the Eighth Coral Reef Symposium (Panama City, 1997). Smithsonian Tropical Research Institute, Panama City, Panama.

McClanahan, T. R. 1997c. Effects of fishing and reef structure on East Africa coral reefs. Pages 1533-1538 in Volume 2 of the Proceedings of the Eighth Coral Reef 
Symposium (Panama City, 1997). Smithsonian Tropical Research Institute, Panama City, Panama.

McClanahan, T. R. 1998. Predation and the distribution and abundance of tropical sea urchin populations. Journal of Experimental Marine Biology and Ecology 221:231-255.

McClanahan, T. R. 1999. Predation and the control of the sea urchin Echinometra viridis and fleshy algae in the path reefs of Glovers Reef, Belize. Ecosystems 2:511-523.

McClanahan, T. R. 2000. Recovery of the coral reef keystone predator, Balistapus undulatus, in East African marine parks. Biological Conservation 94:191-198.

McClanahan, T. R., B. Cokos, and E. Sala. 2002. Algal growth and species composition under experimental control of herbivory, phosphorus and coral abundance in Glovers Reef, Belize. Marine Pollution Bulletin 44 : 441-451.

McClanahan, T. R., H. Glaesel, J. Rubens, and R. Kiambo. 1997. The effects of traditional fisheries management on fisheries yields and the coral-reef ecosystems of southern Kenya. Environmental Conservation 24:1-16.

McClanahan, T. R., A. T. Kamukuru, N. A. Muthiga, M. Gilagabher Yebio, and D. Obura. 1996. Effect of sea urchin reductions on algae, coral and fish populations. Conservation Biology 10:136-154.

McClanahan, T. R., and B. Kaunda-Arara. 1996. Fishery recovery in a coral-reef marine park and its effect on the adjacent fishery. Conservation Biology 10:1187-1199.

McClanahan, T. R., and S. Mangi. 2000. Spillover of exploitable fishes from a marine park and its effect on the adjacent fishery. Ecological Applications 10:1792-1805.

McClanahan, T. R., and S. Mangi. 2001. Comparison of closed area and beach seine exclusion on coral reef fish catches. Fisheries Management and Ecology 8:107-121.

McClanahan, T. R., M. McField, M. Huitric, K. Bergman, E. Sala, M. Nystrom, I. Nordemer, T. Elfwing, and N. A. Muthiga. 2001. Responses of algae, corals and fish to the reduction of macro algae in fished and unfished patch reefs of Glovers Reef Atoll, Belize. Coral Reefs 19:367-379.

McClanahan, T. R., and J. C. Mutere. 1994. Coral and sea urchin assemblage structure and interrelationships in Kenyan reef lagoons. Hydrobiologia 286:109-124.

McClanahan, T. R., and N. A. Muthiga. 1998. An ecological shift in a remote coral atoll of Belize over 25 years. Environmental Conservation 25:122-130.

McClanahan, T. R., N. A. Muthiga, A. T. Kamukuru, H. Machano, and R. Kiambo. 1999. The effects of marine parks and fishing on the coral reefs of northern Tanzania. Biological Conservation 89:161-182.
McClanahan, T. R., M. Nugues, and S. Mwachireya. 1994. Fish and sea urchin herbivory and competition in Kenyan coral reef lagoons: the role of reef management. Journal of Experimental Marine Biology and Ecology 184:237-254.

McClanahan, T. R., and D. Obura. 1995. Status of Kenyan coral reefs. Coastal Management 23:57-76.

McClanahan, T. R., and D. Obura. 1997. Sedimentation effects on shallow coral communities in Kenya. Journal of Experimental Marine Biology and Ecology 209:103-122.

McClanahan, T. R., and S. H. Shafir. 1990. Causes and consequences of sea urchin abundance and diversity in Kenyan coral reef lagoons. Oecologia 83:362-370.

McCook, L. J. 1996. Effects of water quality and herbivores on the distribution of Sargassum within fringing reefs of the central Great Barrier Reef. Marine Ecology Progress Series 139:179-192.

McCook, L. J. 1999. Macroalgae, nutrients and phase shifts on coral reefs: scientific issues and management consequences for the Great Barrier Reef. Coral Reefs 18: 357- 367.

McGoodwin, J. R. 1990. Crisis in the world's fisheries: people, problems, and policies. Stanford University Press, Stanford, California, USA.

McNaughton, S. J. 1977. Diversity and stability of ecological communities: a comment on the role of empiricism in ecology. American Naturalist 111:515- 525.

Meyer, J. L., and E. T . Schultz. 1985. Tissue condition and growth rate of corals associated with schooling fish. Limnology and Oceanography 30:157-166.

Miller, M. W., M. E. Hay, S. L. Miller, D. Malone, E. E. Sotka, and A. M. Szmant. 1999. Effects of nutrients versus herbivores on reef algae: a new method for manipulating nutrients on coral reefs. Limnology and Oceanography 44:1847-1861.

Moran, P. J. 1986. The Acanthaster phenomenon. Oceanography and Marine Biology Annual Review 24:379480.

Munro, J. L. 1996. The scope of tropical reef fisheries and their management. Pages 1-14 in N. V. C. Polunin and C. M. Roberts, edtors. Reef fisheries. Chapman and Hall, London, UK.

Muthiga, N., S. Riedmiller, R. van der Elst, J. MannLang, C. Horrill, and T. R. McClanahan. 2000. Management: status and case studies. Pages 473-505 in T. R. McClanahan, C. R. C. Sheppard, and D. O. Obura, editors. Coral reefs of the Indian Ocean: their conservation and ecology. Oxford University Press, New York, New York, USA. 
Naeem, S. 1998. Species redundancy and ecosystem reliability. Conservation Biology 12:39-45.

Naeem, S., L. J. Thompson, S. P. Lawler, J. H. Lowton, and R. M. Woodfin. 1994. Declining biodiversity can alter the performance of ecosystems. Nature 368:734-737.

Nakamura, T., and R. van Woesik. 2001. Differential survival of corals during the 1998 bleaching event is partially explained by water-flow rates and passive diffusion. Marine Ecology Progress Series 212:301-304.

Nowlis, J. S., and C. M. Roberts. 1999. Fisheries benefits and optimal design of marine reserves. Fishery Bulletin 97:604-616.

Öhman, M. C., A. Rajasuriya, and E. Olafsson. 1997. Reef fish assemblages in north-western Sri Lanka: distribution patterns and influences of fishing practises. Environmental Biology of Fish 49:45-61.

Oliver, J., and B. L. Willis. 1987. Coral spawn slicks in the Great Barrier Reef: preliminary observations. Marine Biology 94:521-529.

Ormond, R., R. Bradbury, S. Bainbridge, K. Fabricus, J. Keesing, L. DeVantier, P. Medlay, and A. Steven. 1988. Test of a model of regulation of Crown-of- Thorns starfish by fish predators. Pages 190-207 in R. H. Bradbury, editor. Acanthaster and the coral reef: a theoretical perspective. Springer-Verlag, Townsville, Australia.

Ostrander, G. K., K. M. Armstrong, E. T. Knobbe, D. Gerace, and E. P. Scully. 2000. Rapid transition in the structure of a coral reef community: the effects of coral bleaching and physical disturbance. Proceedings of the National Academy of Science 97:5297-5302.

Pandolfi, J. M. 1996. Limited membership in Pleistocene reef coral assemblages from the Huon Peninsula, Papua New Guinea: constancy during global changes. Paleobiology 22:152-176.

Pandolfi, J. M. 2002. Coral community dynamics at multiple scales. Coral Reefs 21:13-23.

Patterson, K. L., D. S. Santavy, J. G. Campbell, J. W. Porter, L. G. MacGlaughlin, E. Mueller, and E. C. Peters. 1997. Coral diseases in the eastern Florida Keys, New Grounds, and the Dry Tortugas. American Zoologist 37:13.

Phinney, J. T., Muller-Karger, F., Dustan, P., and J. Sobel. 2001. Using remote sensing to reassess the mass mortality of Diadema antillarum 1983-1984. Conservation Biology 15: 885-891.

Pilson, M. E. Q., and S. B. Betzer. 1973. Phosphorus flux across a coral reef. Ecology 54:581-584.

Pittock, A. B. 1999. Coral reefs and environmental change: adaptation to what? American Zoologist 39:10-29.
Planes, S., A. Levefre, P. Legendre, and R. Galzin. 1993. Spatio-temporal variability in fish recruitment to a coral reef (Moorea, French Polynesia). Coral Reefs 12:105-113.

Polunin, N. V. C. 1984. Do traditional marine "reserves" conserve? A view of Indonesian and new Guinean evidence. Senri Ethnological Studies 17:266-283.

Polunin, N. V. C. 1988. Efficient uptake of algal production by single resident herbivorous fish on the reef. Journal of Experimental Marine Biology and Ecology 123:61-76.

Polunin, N. V. C. 1996. Trophodynamics of reef fisheries productivity. Pages 361-377 in N. V. C. Polunin and C. M. Roberts, editors. Reef fisheries. Chapman and Hall, London, UK.

Polunin, N. V. C., and J. K. Pinnegar. 2002. Trophic ecology ad the structure of marine food webs. Pages 310320 in P. J. B. Hart and J. D . Reynolds, editors. Handbook of fish and fisheries. Volume I. Blackwell, Oxford, UK.

Polunin, N. V. C., and C. M. Roberts. 1993. Greater biomass and value of target coral-reef fishes in two small Caribbean marine reserves. Marine Ecology Progress Series 100:167-176.

Polunin, N. V. C., C. M. Roberts, and D. Pauly. 1996. Developments in tropical reef fisheries science and management. Pages 361-377 in N. V. C. Polunin and C. M. Roberts, editors. Reef fisheries. Chapman and Hall, London, UK.

Randall, J. E. 1967. Food habits of reef fishes of the West Indies. Studies in Tropical Oceanography 5:665-847.

Randall, R. H., and C. Birkeland. 1978. Guam's reefs and beaches. Part II. Sedimentation studies at Fouha Bay and Ylig Bay. University of Guam Marine Laboratory Report Number 47. University of Guam, Mangilao, Guam.

Reaka-Kudla, M. L., J. S. Feingold, and W. Glynn. 1996. Experimental studies of rapid bioerosion of coral reefs in the Galapagos Islands. Coral Reefs 15:101-109.

Richardson, L. L. 1998. Coral diseases: what is really known? Trends in Ecology and Evolution 13:438-443.

Risk, M. J., P. W. Sammarco, and E. N. Edinger. 1995. Bioerosion in Acropora across the continental shelf of the Great Barrier Reef. Coral Reefs 14:79-86.

Risk, M. J., and B. Sluka. 2000. The Maldives: a nation of atolls. Pages 325-351 in T. R. McClanahan, C. R. C. Sheppard, and D. O. Obura, editors. Coral reefs of the Indian Ocean: their ecology and conservation. Oxford University Press, New York, New York, USA.

Roberts, C. M. 1995. Rapid build-up of fish biomass in a Caribbean marine reserve. Conservation Biology 9:815-826.

Roberts, C. M. 1997. Connectivity and management of 
Caribbean coral reefs. Science 278:1454-1457.

Roberts, C. M., and N. V. C. Polunin. 1991. Are marine reserves effective in management of reef fisheries? Review in Fish Biology and Fisheries 1:65-91.

Roberts, C. M., and N. V. C. Polunin. 1993. Marine reserves: simple solutions to managing complex fisheries? Ambio 22:363-368.

Robertson, D. R. 1991. Increases in surgeonfish populations after mass mortality of the sea urchin Diadema antillarum in Panama indicate food limitation. Marine Biology 111:437-444.

Rogers, C. S. 1993. Hurricanes and coral reefs: the intermediate disturbance hypothesis revisited. Coral Reefs 12:127-137.

Rose, C. S., and M. J. Risk. 1985. Increase in Cliona delitrix infestation of Montastrea cavernosa heads on an organically polluted portion of the Grand Cayman fringing reef. Marine Ecology 6:345-363.

Rosenau, J. N. 1997. Enlarged citizen skills and enclosed coastal seas. Pages 329-335 in L. A. Brooks and S. D. Vandeveer, editors. Saving the seas: values, scientists, and international governance. Cornell Maritime Press, Centreville, Maryland, USA.

Rowan, R., N. Knowlton, A. Baker, and J. Jara. 1997. Landscape ecology of algal symbionts creates variation in episodes of coral bleaching. Nature 388:265-269.

Ruddle, K., E. Hviding, and R. Johannes. 1992. Marine resources management in the context of customary tenure. Marine Resource Economics 7:249-273.

Ruddle, K. 1996. Traditional management of reef fishing. Pages 315-335 in N. V. C. Polunin and C. M. Roberts, editors. Reeffisheries. Chapman and Hall, London, UK.

Russ, G. R., and A. C. Alcala. 1989. Effects of intense fishing pressure on an assemblage of coral reef fishes. Marine Ecology Progress Series 56:13-27.

Russ, G. R., and A. C. Alcala. 1996. Do marine reserves export adult fish biomass? Evidence from Apo Island, Central Philippines. Marine Ecology Progress Series 132:19.

Sammarco, P. W. 1980. Diadema and its relationship to coral spat mortality: grazing, competition, and biological disturbance. Journal of Experimental Marine Biology and Ecology 45:245-272.

Sammarco, P. W. 1982. Echinoid grazing as a structuring force in coral communities: whole reef manipulations. Journal of Experimental Marine Biology and Ecology 61:31-35.

Scoffin, T. P. 1993. The geological effects of hurricanes on coral reefs and the interpretation of storm deposits. Coral Reefs 12:203-221.

Sheppard, C. R. C. 2000. Coral reefs of the western Indian Ocean: an overview. Pages 3-38 in T. R. McClanahan, C. R. C. Sheppard, and D. O. Obura, editors. Coral reefs of the Indian Ocean: their ecology and conservation. Oxford University Press, New York, New York, USA.

Shulman, M. J., and D. R. Robertson. 1997. Changes in the coral reef of San Blas, Caribbean Panama: 1983 to 1990. Coral Reefs 15:231-236.

Simberloff, D. 1991. Keystone species and community effects of biological introductions. Pages 1-19 in L. Ginzburg, editor. Assessing ecological risks of biotechnology. Butterworth-Heinemann, Boston, Massachusetts, USA.

Smith, A. H., and F. Berkes. 1991. Solutions to the 'tragedy of the commons': sea-urchin management in St. Lucia, West Indies. Environmental Conservation 18:131136.

Smith, S. V. 1983. Coral reef calcification. Pages 240-247 in D. J. Barnes, editor. Perspectives on coral reefs. Brian Clouster Publisher, Manuka, Australia.

Smith, S. V., W. J. Kimmerer, E. A. Laws, R. E. Brock, and T. W. Walsh. 1981. Kaneohe Bay sewage diversion experiment: perspectives on ecosystem responses to nutritional perturbation. Pacific Science 35:279-402.

Smith, T. D. 1988. Stock assessment methods: the first fifty years. Pages 1-34 in J. A. Gulland, editor. Fish population dynamics. John Wiley, Chichester, UK.

Smith, A., and P. Dalzell. 1993. Fisheries resources and management investigations in Woleai Atoll, Yap State, Federated States of Micronesia. Inshore Fisheries Research Project Technical Document Number 4. Inshore Fisheries Research Project, Secretariat of the Pacific Community, Noumea Cedex, New Caledonia.

Spear, T. T. 1978. The kaya complex: a history of the Mijikenda peoples of the Kenya Coast to 1900. Kenya Literature Bureau, Nairobi, Kenya.

Steneck, R. S., and M. N. Dethier. 1994. A functional group approach to the structure of algal-dominated communities. Oikos 69:476-498.

Swearer, S. E., J. E. Caselle, D. W. Lea, and R. R. Warner. 1999. Larval retention and recruitment in an island population of a coral-reef fish. Nature 402:799-802.

Szmant, A. M. 1997. Nutrient effects on coral reefs: a hypothesis on the importance of topographic and trophic complexity to reef nutrient dynamics. Pages 1527-1532 in Volume 2 of the Proceedings of Eighth International Coral Reef Symposium (Panama City, 1997). Smithsonian Tropical Research Institute, Panama City, Panama. 
Tanner, J. E. 1995. Competition between scleractinian corals and macroalgae: an experimental investigation of coral growth, survival and reproduction. Journal of Experimental Marine Biology and Ecology 190:151-168.

Thomson, D. B. 1980. Conflict within the fishing industry. ICLARM Newsletter 3:3-4.

Thompson, M., and A. Trisoglio. 1997. Managing the unmanageable. Pages 107-127 in L. A. Brooks and S. D. Vandeveer, editors. Saving the seas: values, scientists, and international governance. Cornell Maritime Press, Centreville, Maryland, USA.

Tilman, D., and J. A. Downing. 1994. Biodiversity and stability in grasslands. Nature 367:363-365.

Tilman, D., D. Wedin, and J. Knops. 1996. Productivity and sustainability influenced by biodiversity in grassland ecosystems. Nature 379:718-720.

Tomascik, T., A. J. Mah, A. Nontji, and M. K. Moosa. 1997. The ecology of the Indonesian seas. Periplus, Hong Kong.

Tomascik, T., and F. Sanders. 1987. Effects of eutrophication on reef building corals. II. Structure of scleractinian coral communities on fringing reefs, Barbados, West Indies. Marine Biology 94:63-75.

Tomascik, T., R. V. Woesik, and A. J. Mar. 1996. Rapid coral colonization of a recent lava flow following a vocanic eruption, Banda Islands, Indonesia. Coral Reefs 15:69-176.

Tribble, G. W., M. J. Atkinson, F. J. Sansone, and S. V. Smith. 1994. Reef metabolism and end-upwelling in perspective. Coral Reefs 13:199-201.

Umar, J., L. J. McCook, and I. R. Price. 1998. Effects of sediment deposition on the seaweed Sargassum on a fringing coral reef. Coral Reefs 17: 169-177.

van Katwijk, M. M., N. F. Meier, R. Loon, E. M. Hove, W. B. J. T. Giesen, G. Velde, and C. Hartog. 1993. Sabaki river sediment load and coral stress: correlation between sediments and condition of the Malindi-Watamu reefs in Kenya (Indian Ocean). Marine Biology 117:675683.

Veron, J. E. N. 1995. Corals in space and time: the biogeography and evolution of the Scleractinia. University of New South Wales Press, Sydney, Australia.

Wilkinson, C. R., D. M. Willams, P. W. Sammarco, R. W. Hogg, and L. A. Trott. 1984. Rates of nitrogen fixation on coral reefs across the continental shelf of the central Great Barrier Reef. Marine Biology 80:255-262.

Williams, I. D., and N. V. C. Polunin. 2000. Differences between protected and unprotected Caribbean reefs in attributes preferred by dive tourists. Environmental Conservation 27: 382-391.
Williams, I. D., and N. V. C. Polunin. 2001. Large-scale associations between macroalgal cover and grazer biomass on mid-depth reefs in the Caribbean. Coral Reefs 19:358356.

Williams, I. D., N. V. C. Polunin, and V. Hendrick. 2001. Limits to grazing by herbivorous fishes and the impact of low coral cover on macroalgal abundance on a coral reef in Belize. Marine Ecology Progress Series 222: 187-196.

Williams, S. L., and R. C. Carpenter. 1988. Nitrogenlimited primary productivity of coral reef algal turfs: potential contribution of ammonium excreted by Diadema antillarum. Marine Ecology Progress Series 47:145-152.

Woodley, D. J., E. A. Chornesky, P. A. Clifford, J. B. C. Jackson, L. S. Kaufman, N. Knowlton, J. C. Land, M. P. Pearson, J. W. Porter, M. C. Rooney, K. W. Rylaarsdam, V. J. Tunnicliffe, C. M. Wahle, J. L. Wulff, A. S. G. Curtis, M. D. Dallmeyer, B. P. Jupp, M. A. R. Koehl, J. Niegel, and E. M. Sides. 1981. Hurricane Allen's impact on Jamaican coral reefs. Science 214:749-755.

Yentsch, C. S., C. M. Yentsch, J. J. Cullen, B. Lapointe, D. A. Phinney, and S. W. Yentsch. 2002. Sunlight and water transparency: cornerstones in coral research. Journal of Experimental Marine Biology and Ecology 268 :171-183.

Young, T. P. 1996. High montane forest and afroalpine ecosystems. Pages 401-424 in T. R. McClanahan and T. P. Young, editors. East African ecosystems and their conservation. Oxford University Press, New York, New York, USA.

Zerner, C. 1994. Tracking sasi: the transformation of a central Moluccan reef management institution in Indonesia. Pages 19-32 in A. T. White, L. Z. Hale, Y. Renard, and L. Cortes, editors. Collaborative and community-based management of coral reefs: lessons from experience. Kumarian Press, Bloomfield, Connecticut, USA. 